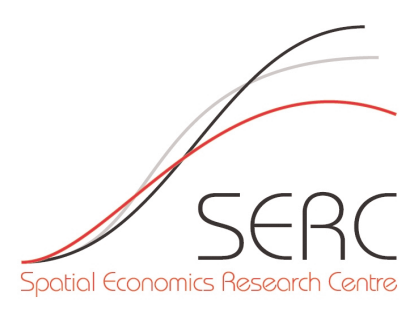

\title{
Local Economic Conditions and the Nature of New Housing Supply
}

Christian A. L. Hilber (SERC, CEP \& London School of Economics)

Jan Rouwendal (VU University, Tinbergen Institute)

Wouter Vermeulen (CPB Netherlands Bureau for Economic Policy Analysis, VU University)

August 2014 
This work is part of the research programme of the independent UK Spatial Economics Research Centre funded by a grant from the Economic and Social Research Council (ESRC), Department for Business, Innovation \& Skills (BIS) and the Welsh Government. The support of the funders is acknowledged. The views expressed are those of the authors and do not represent the views of the funders.

(C) C. A. L. Hilber, J. Rouwendal and W. Vermeulen, submitted 2014 


\title{
Local Economic Conditions and the Nature of New Housing Supply
}

\author{
Christian A. L. Hilber* \\ Jan Rouwendal** \\ Wouter Vermeulen***
}

\section{August 2014}

\author{
* Spatial Economics Research Centre, London School of Economics and Political Science \\ and Centre for Economic Performance \\ ** VU University and Tinbergen Institute \\ *** CPB Netherlands Bureau for Economic Policy Analysis and VU University
}

The authors wish to thank Peter Englund, Ingrid Gould-Ellen, Lawrence Katz, Steven Laufer, seminar/workshop participants at the CPB, LSE, University of Amsterdam and University of Reading and participants at the ERES, NARSC/UEA and Swiss Economists Abroad conferences for helpful comments and suggestions. We are grateful to Maurice de Kleijn for help with GIS related work. Sejeong Ha provided excellent research assistance. Christian Hilber acknowledges a research grant from the Suntory and Toyota International Centre for Economics and Related Disciplines (STICERD) and a travel grant from the Investment Property Forum Education Trust (IPFET). Wouter Vermeulen acknowledges financial support from the HABIFORM program on innovative land use. The remaining errors are the sole responsibility of the authors. 


\begin{abstract}
We present a modified open monocentric city model that assumes that land is available for conversion into new housing throughout the city. The model predicts that positive local income shocks (i) increase the city's share of multi-family housing in new construction and (ii) lead to the construction of smaller units. We exploit the metro area samples of the American Housing Survey from 1984 to 2004 and find support for both predictions. We confirm that the adjustment process is driven by migration and is hindered by strict local land use control. Our findings imply that tight regulation may hamper metro area level labor market adjustment to positive economic shocks not only through limits on the quantity of newly supplied units but also by constraining their type to single-family houses and larger units that may be less suitable for would-be-migrants.
\end{abstract}

Keywords: Local economic conditions, open monocentric city model, land conversion, housing supply, housing type, housing consumption, land use regulation, migration JEL Classifications: R11, R21, R31, R52 


\section{Introduction}

The composition of the existing housing stock in a city does not only determine the character of a city - its skyline - but affects a host of important attributes such as the city's household composition, its homeownership propensity, or its population density and hence, conceivably, productivity. As a consequence of the durability of housing, if the nature of the existing housing stock is important for a location's fortunes, then so should be the nature of new housing supply. Housing units built in a certain period - reflecting the demand and supply conditions at that point in time - last for several decades and sometimes centuries, continuing to exert positive and negative externalities associated with their characteristics.

Little is known to date about the determinants of the characteristics of new housing supply. In particular, little is known about how local economic shocks affect the nature of the newly built housing stock. In this paper we explore empirically how local economic conditions, at the time when new housing developments are being planned and built, affect the composition of new housing supply, i.e., whether new housing is of single-family or multi-family type and the size of newly built housing units in square feet.

To guide our empirical analysis, we first derive predictions from a modified version of the open monocentric city model that assumes that some land - either already developed or still undeveloped - is available for conversion into new housing throughout the city. Unlike the standard open monocentric city model that implicitly assumes that the city is rebuilt from scratch in each period, our implicit assumptions are that (i) the building stock is durable and depreciates slowly and at some point can become obsolete and is replaced and (ii) during the outward development process of a city, some pockets of land may remain undeveloped ${ }^{1}$ but are subject to infill at a later stage. Formally we assume that some (re)development takes place all over the urban area and that the share of land that is converted into new housing may vary between more central and more peripheral locations, consistent with stylized facts derived from the American Housing Survey (AHS) and empirical evidence presented by e.g. Brueckner and Rosenthal (2009), Burchfield et al. (2006), or McDonald and McMillen (2000). We also assume that conversion rates depend on local income levels, capturing the idea that the opportunity cost of keeping land open or of not redeveloping existing defunct property stock increases with local income. Given these assumptions, our model predicts that positive local income shocks (i) increase the share of multi-family housing in the city and (ii) cause the construction of smaller units.

The economic intuition for these predictions is, at a first glance at least, not straightforward: Housing is a normal good and hence one might expect that local economic booms induce the construction of more single-family units and of more large units, whereas local economic

\footnotetext{
${ }^{1}$ In practice there are numerous reasons for why land is not uniformly developed at each distance to the center. For example, undeveloped land varies in soil quality and topography and consequently in the development cost. Also, heterogeneous owners of undeveloped land may differ in their reservation price, at which they are willing to develop their land. Undeveloped land also has a real option value and the valuation of this option may too vary across heterogeneous owners. Certain sites may be off limits to developers because of zoning or other types of government intervention. Finally, certain undeveloped sites (in between developed ones) may be awkward and costly to develop because of their unusual shapes so not viable at the time of general outward development. But these sites may become viable for development at a later stage because of increased demand pressures.
} 
crises might have the opposite effect. However, this view ignores the important insight that residents can relocate across cities and that such relocation may equalize differences in living standards across cities. In a setting with an open monocentric city, where households can relocate freely between cities and housing is assumed to be perfectly malleable, a positive city-level income shock temporarily increases the utility of its residents compared to the utility of the outside option. This attracts more migrants into the city and thereby increases land and house prices and reduces the quantity of housing consumed at each distance from the Central Business District (CBD). In the new spatial equilibrium, household migration exactly equalizes the utility of households across cities.

The higher land prices also invoke a substitution away from land to capital in the housing production process, implying more capital-intensive housing in spatial equilibrium, again, at each distance from the CBD. But this does not necessarily imply that in the metro area as a whole the capital intensity of new construction must increase. This is because a positive income shock also generates more new housing development with low capital intensity at the urban fringe. Hence, the aggregate effect is a priori ambiguous. One contribution of our theoretical analysis is that we derive the predictions that a positive income shock increases the share of construction of multi-family housing and leads to the construction of smaller units at the aggregate metro area level.

In order to test our model predictions we turn to the AHS. We gather information on over 700,000 housing units, including their year of construction, from all AHS Metropolitan Statistical Area (MSA)-samples between 1984 and 2004. A key assumption in our empirical strategy is that after a unit is built, the type (single-family vs. multi-family) and the size of the unit (floor area in square feet) remain unchanged for a few years. In our baseline specification we assume that the fraction of units that increase their floor size within the first ten years after construction is small. (In a robustness check we narrow down this time window to five years.) Building on this plausible assumption, measures of the type and size of new housing supply can be created for each MSA by taking means conditional on the year of construction. These measures are subsequently related to one-year lagged MSA-level income per capita and construction industry-wages in a fixed effects panel data analysis that fully controls for timeinvariant heterogeneity and trends at the national level. Ultimately, we end up with a panel dataset consisting of 47 MSAs and nearly 2000 observations.

Our fixed effects baseline estimates provide strong support for the two model predictions that positive local income shocks are associated with the construction of more multi-family housing and smaller units. To illustrate the magnitude of the effects, consider the case where income is constant everywhere in the country except in one metro area. (Alternatively we could assume that income grows more strongly in the focal metro area than nationally without loss of generality.) This metro area receives a one-time productivity shock that raises local income by 10 percent from year $\tau$-1 to year $\tau$. From year $\tau$ onwards income remains again unchanged. Our baseline result implies that such a shock permanently raises the share of multi-family units in new construction by 6.4 percentage points from period $\tau$ onwards.

To put this into context, say a city consists of 1 million housing units, 30 percent of which are of the multi-family type prior to the shock. Say 40,000 new units are being built each year, 
either replacing existing run-down housing stock, converting brownfield land, or being built on open land. This implies that prior to the shock 12,000 new multi-family units (30 percent of 40,000) are built each year. Holding the total number of new units constant, our estimates imply that the positive income shock will induce a permanent increase in construction of multi-family units from 12,000 to $14,560(=(0.3+0.064) \times 40,000)$ in each subsequent period. A one-time positive income shock of 10 percent will thus after 10 years generate an additional 25,600 (10 times 2,560) multi-family units and correspondingly fewer single-family units. ${ }^{2}$ Although this illustrative example suggests that our estimated effects are not very large, since the effects are permanent in nature and cumulative over time, they are quantitatively meaningful in the long-run. Moreover, our derived quantitative effects are consistent with the observation that the built housing stock in a city typically only changes gradually and slowly due to the extreme durability and thus slow depreciation of housing. Similarly, our other base line results are meaningful and plausible. A one-time 10 percent increase in local income, holding national level income constant, reduces the square footage of an average singlefamily house by 119 square feet (4.8 percent) and that of an average multi-family unit by 350 square feet (16.8) percent.

Our theoretical model implies that our findings are driven by migration across cities in response to local income shocks. Using a Bartik (1991)-type identification strategy, we indeed find supporting evidence that migration in response to changing local economic conditions (i.e., local labor demand shocks) is the underlying force driving our findings. Put differently, our instrumental variable estimates are indicative that local labor demand shocks, via inducing migration, cause changes in the composition of new housing supply.

Our theoretical setting implicitly assumes that the nature of new housing supply in a city is purely driven by market forces. In many American cities and, in fact, in many cities across the world, however, new housing supply is in crucial ways determined by regulatory constraints on land use and building construction. That is, land use regulation may well drive a wedge between the new housing supplied in a city and the counterfactual outcome of a setting where new construction is purely determined by market forces. Empirically, we indeed find that the adjustment processes are confined to MSAs with comparably lax land use regulation. Our findings imply that severe land use controls may hamper MSA-level labor market adjustment not only through limits on the quantity of newly supplied housing units (Glaeser et al., 2006; Saks, 2008), but also by constraining their type to single-family houses and larger units that are less suitable for would-be-migrants.

Our paper makes three contributions to the existing literature. First, we shed light on the link between local economic conditions and the nature of new housing supply. Second, we propose a modified version of the open monocentric city model that explicitly distinguishes between multi-family and single-family units and reconciles the theoretical framework with observed regularities with respect to new residential development. Third, we explore the role of land use regulation in this context and reveal that our findings are confined to metro areas

\footnotetext{
${ }^{2}$ This back of the envelope calculation assumes that the income differential does not converge. Blanchard and Katz (1992) however document a tendency for regional income differentials to converge. To the extent that there is convergence over time, the effect will get smaller over time and the aggregate effect will be less pronounced.
} 
with lax land use controls, suggesting a mismatch between the newly constructed housing stock and the preferences of would-be-migrants.

Our paper is structured as follows. In Section 2 we briefly review the related literature. Section 3 provides a theoretical framework that guides our empirical analysis. Section 4 describes the data and empirical strategy in more detail. In Section 5 we present results. Conclusions are offered in the final section.

\section{Background and related literature}

Our theoretical framework builds upon the seminal work on the monocentric city model (MCM) by Alonso (1964), Mills (1967, 1972), and Muth (1969), and, in particular on the Muth model that incorporates housing construction (see e.g. Brueckner, 1987; Fujita, 1989). One limitation of the standard MCM is the extreme assumption that the conversion rate of the existing housing stock into new housing stock is 1 throughout the city - housing capital is assumed to be perfectly malleable. Put differently: the city is rebuilt from scratch in every single period. The reverse extreme assumption is perfectly durable housing capital. In such a setting new construction of (single-family) housing can only take place within small concentric rings at the edge of the city, where agricultural land is converted into housing.

Neither extreme squares well with empirical evidence. The American Housing Survey (AHS) - the data source underlying our empirical analysis - reveals that housing construction takes place all over metropolitan areas. The rate of new construction relative to the existing housing stock is only about twice as high in the suburbs as in the city center. In a similar vein, Brueckner and Rosenthal (2009) document the percentage of housing stock in 2000 that is under 10 years old as a function of distance to the city center. While they find that newer housing is disproportionately located in suburban areas, they also document that except for the largest cities, the percentage hardly varies between 10 and 40 miles from the city center. New residential construction is not confined to greenfield or brownfield sites but also occurs to replace older housing, typically at higher density. Such conversion takes place especially in older parts of cities, in or close to the center (Brueckner and Rosenthal, 2009). In these areas there is often also a considerable amount of brownfield development as locations used previously by manufacturing or other industries that left the city are converted into housing. Appendix Figure A1 (in Appendix A) illustrates, for the case of New York City in 2012, the stylized fact that local residential development takes place throughout the city. ${ }^{3}$

Both, the standard MCM and models with perfect durability ignore the important fact that the housing stock is durable but depreciates (see e.g., Brueckner, 2000). In models with durability and depreciation the possibility that multi-family and single-family housing are not strictly separated in different concentric zones, as is the case when housing capital is malleable, arises naturally. Upward sloping and even discontinuous building height contours can result. Moreover, in the face of uncertainty, urban development does not necessarily occur from the

\footnotetext{
${ }^{3}$ The map is derived from the NYC Department of City Planning's publicly available MapPLUTO data set. This includes both residential units and year built for every parcel in New York City. The data can be accessed via: http://www.nyc.gov/html/dcp/html/bytes/dwn pluto mappluto.shtml\#mappluto (last accessed: July 22, 2014).
} 
city center outwards. Instead there may be leapfrog development, in which some land within the city boundary remains vacant (Capozza and Helsley, 1990). ${ }^{4}$

The theoretical prediction of leapfrogging is consistent with an important stylized fact: pockets of land are open and developable within most US cities. Remote-sensing information on land use dynamics points to the importance of infill: Burchfield et al. (2006) document that scattered and incomplete residential development is the rule rather than the exception. Suburban developments tend to leave substantial amounts of space open, which may become an important source of new construction within the urban fringe at a later stage. They also provide evidence that areas that were about half developed in 1976 were subject to the most intense residential development between 1976 and 1992. In a similar vein, McDonald and McMillen (2000) examine the location of residential and commercial real estate development in the Chicago metro area between 1990 and 1996. Their findings indicate, among other things, that new residential development did not just take place at the edge of the Chicago metro area but took place throughout the metro area, forming clusters of their own between major highways.

In our model we attempt to reconcile the open monocentric city framework with the stylized facts that (i) housing is durable but depreciates and is ultimately redeveloped and (ii) there are pockets of open land even close to the city center and these pockets often are developed at a later stage. Specifically, we assume that some fraction, $\alpha$, of all land (developed or undeveloped) is redeveloped or newly developed, respectively, in each period. We assume that this fraction depends on the local income in the city (relative to the national average) and we allow it to differ between the core and the periphery of the city.

Our paper also relates to the housing supply literature. This literature has either focused on new housing supply in units or on the "volume" of residential investment at the national level, thus aggregating all composition and quality aspects into one single variable and ignoring the spatial dimension (e.g., DiPasquale, 1999). Studies in the former category generally focus on the single-family sector, thus ignoring the supply of multi-family housing. Heterogeneity within the single-family-sector is ignored as well, even though the hedonic literature suggests that the value of single-family housing units varies widely depending on their attributes.

At the metro area level, in a cross-section and in the absence of strict land use controls (zoning), the housing stock composition can be expected to be mainly determined by the strength of agglomeration and dispersion forces; larger and denser cities with stronger agglomeration forces should have more high-rise (multi-family) buildings in the center and a steeper residential land price gradient. A growing body of the literature, however, highlights the significant impact that land use regulations exert on housing supply, at least in some metro areas. For example, in US metro areas where regulation is more stringent, residential construction in units is less responsive to price changes (Green et al., 2005; Quigley and Raphael, 2005) and shifts in labor demand translate into higher wages and house prices, rather

\footnotetext{
${ }^{4}$ An alternative explanation for leapfrogging is that people have a preference for housing that is close to open space (Turner, 2005). See also Burchfield et al. (2006) for a summary of the related theoretical literature.
} 
than into more jobs and houses (Glaeser et al., 2006; Saks, 2008). ${ }^{5}$ Hilber and Turner (2014) explore the role that land use constraints exert on homeownership attainment. They demonstrate that the US mortgage interest deduction boosts homeownership attainment of higher income households in less tightly regulated housing markets but that in restrictive places an adverse effect exists.

Tight land use regulation likely also influences the housing stock composition in important ways. Strict height controls for example prevent high-rise buildings. Historic preservation prevents redevelopment at higher density. Zoning determines how much multi-family or single-family housing can be built. Other types of controls (e.g., minimum lot size restrictions) directly affect the size of the housing units (and thereby the population density and the household composition). The overall effect of restrictive land use regulation may well be that it drives a wedge between the existing housing stock and newly constructed housing on the one hand and the housing that is desired by migrants on the other. We explore this proposition in the theoretical and empirical analyses that follow.

Another strand of the urban economics literature considers the link between the housing stock (supply) and the corresponding household composition. Affluent households in the United States tend to sort into communities that predominately consist of spacious and expensive single-family homes. As a consequence, such communities have higher local property tax income per capita and therefore can offer better local public schools and other local public services. In contrast, low income households prefer to sort into inexpensive lower "quality" housing in decaying areas (Rosenthal, 2008) ${ }^{6}$ or into areas where government programs have contributed to "affordable housing" (Baum-Snow and Marion, 2009). Minimum lot size restrictions, imposed by affluent households in order to keep less well-off households at bay, tend to reinforce such sorting by income based on the underlying built environment.

Our study also ties into the literature on the determinants and economic consequences of homeownership. Particularly relevant to our investigation, a few studies have pointed out that multi-family units are significantly more likely to be renter-occupied ${ }^{7}$ (Coulson and Fisher, 2014; Hilber, 2005 and 2014; Linneman, 1985). Hilber (2005 and 2014) provide empirical evidence for the United States and Europe, respectively. Coulson and Fisher (2014) and Linneman (1985) provide theoretical explanations.

To the extent that the construction of more multi-family housing causes a decrease in the homeownership propensity, our study has direct relevance for the voluminous literature on the social and economic consequences of homeownership. The literature suggests that homeownership is linked to (i) housing maintenance (e.g., Galster, 1983), (ii) investment in local public goods such as public schools (e.g., Hilber and Mayer, 2009), (iii) investment in social capital (e.g., DiPasquale and Glaeser, 1999; Hilber, 2010; Hoff and Sen, 2005), (iv)

\footnotetext{
${ }^{5}$ See Duranton and Puga (2014) for a discussion of the wider implications of land use regulation on urban economic growth.

${ }^{6}$ Glaeser and Gyourko (2005) show that the same mechanism is at play at the geographical level of MSAs. In declining cities where labor demand is weak, house prices are low but through decay, the housing stock adjusts only slowly to these conditions. This leads to a sorting process in which people with lower human capital levels stay in declining cities in order to benefit from relatively cheap housing.

${ }^{7}$ According to the national American Housing Survey (AHS), only about one in seven multi-family units in the US are owner-occupied. Roughly the reverse is the case for single-family units.
} 
labor market outcomes and entrepreneurship (e.g., Blanchflower and Oswald, 2013; Bracke et al., 2014; Harding and Rosenthal, 2013; Oswald, 1996), or (v) local political participation and land use regulation (e.g., Ahlfeldt and Maennig, 2013; Fischel, 2000 and 2001; Hilber and Robert-Nicoud, 2013; Ortalo-Magné and Prat, 2014). ${ }^{8}$

\section{Theoretical framework}

In this section we present a simple modified version of the open monocentric city model. Our model differs from the standard model in that (i) we explicitly distinguish between two types of housing; single-family and multi-family, (ii) we assume that in each period a small fraction of all land - already developed or undeveloped - is converted into new residential development throughout the city, and (iii) the conversion rate can differ between more central and more peripheral locations.

Our model is static in that we compare the income $y$ in a focal city with the outside income $y^{*}$. In the steady-state $y_{0}$ equals $y^{*}$. Our model predicts that if $y_{0}$ increases to $y$ such that $y>y^{*}$, this will increase the share of multi-family housing in new construction and will lead to new construction of smaller units. By implication, if income grows more strongly in our focal city than in the nation as a whole, the prediction remains that the share of multi-family housing in new construction will increase in the focal city and newly constructed units will be smaller compared to the counterfactual with equal income growth rates.

The empirical implication is that - absent of land use regulations and other restrictions - cities that receive a positive income shock, controlling for national-level shocks and city specific unobserved characteristics (captured through the inclusion of year and metro area fixed effects), will observe an increase in the share of construction of capital-intensive multi-family housing and will see smaller units being built.

We proceed discussing the various components and specific features of our model.

\subsection{Single- and multi-family housing in a monocentric city}

\section{Demand for floor space}

We consider a monocentric city with a homogeneous population and two types of housing: single-family $(s f)$ and multi-family $(m f)$. The generalization to an arbitrary number of $m f$ dwelling types is discussed in Appendices B and C. Utility is characterized by the function $u=u(c, s, i)$, where $c$ is a composite consumption good, $s$ is the amount of floor space, and $i$ $(=s f, m f)$ indicates the dwelling type. Households can switch between dwelling types, however, in each period they can only inhabit one type. Utility is continuously differentiable, increasing and quasi-concave in $c$ and $s$. Floor space in $m f$ units is assumed to be inferior, which is reflected in the assumption that $u(c, s, s f)>u(c, s, m f)$ for all $c$ and $s .{ }^{9}$ The inverse

\footnotetext{
${ }^{8}$ Dietz and Haurin (2003) provide a comprehensive survey on the externalities of homeownership such as higher political participation, improved health and self-esteem, better child outcomes or greater investment in local social capital.

${ }^{9}$ We treat floor space in $m f$ and $s f$ units as inherently different and, specifically, $m f$ floor space as inferior because apartments are much more prone to negative externalities such as noise from neighbors. In the extension to an arbitrary number of $m f$ housing types in Appendices B and C, we also assume that the floor space of $m f$ units is inferior, but we assume that consumers are indifferent to building height within the $m f$ sector.
} 
of the utility function with respect to $c, z=z(u, s, i)$, may be interpreted as the amount of composite consumption good that has to be offered to a household that lives in a housing unit of type $i$ with an amount $s$ of floor space, in order to guarantee utility level $u$. Its partial derivative with respect to $s$ equals minus the willingness to pay for floor space. By assumption, this willingness to pay is always larger for floor space in $s f$ housing: $-\partial z(u, s, s f) / \partial s>-\partial z(u, s, m f) / \partial s$ for all $u$ and $s$.

For simplicity we assume that all housing is rented and that rent levels adjust fully to changes in market conditions. ${ }^{10}$ Let $p_{i}$ denote the rent of a square unit of floor space in housing of type $i$. Normalizing the price of the composite consumption good to unity, we can then write the household budget constraint as $y-t x=c+p_{i} s_{i}$, where $y$ denotes income, $x$ is the distance to the CBD, and $t$ the transportation cost per distance unit. Equalization of utility within the city requires that $p_{i}$ is equal to the bid rent for floor space. This is the maximum amount a household can afford to pay for a unit of floor space, while still being able to reach utility level $u$ :

$$
\Psi(u, x, y, i)=\max _{s} \frac{y-t x-z(u, s, i)}{s} .
$$

For the floor size $s$ that solves this optimization problem, it holds that:

$$
-\frac{\partial z(u, s, i)}{\partial s}=\frac{y-t x-z(u, s, i)}{s} .
$$

This equation states that the marginal willingness to pay for floor space equals the amount of money per unit of floor space that is available to a household that has to reach utility level $u$. Hence, the equilibrium rent level for each type of housing is equal to the corresponding marginal willingness to pay. These bid rents are decreasing convex functions of the distance to the city center, and it may be shown that the bid rent function for floor space in $m f$ units lies below that for floor space in $s f$ units. ${ }^{11}$

\section{Demand for developable land}

Developers build and rent out $s f$ and $m f$ units in perfectly competitive markets, implying that all their profits disappear into bid rents for residential land. The two types of housing are distinguished by the number of square feet of floor space per unit of land. In our model, buildings containing $m f$ units, have $F$ square units of floor space per square unit of land, whereas $s f$ housing has one square unit of floor space per unit of land. Our data indicate that the average number of floors roughly equals 2 in $s f$ housing and 3 in $m f$ housing. Our model would capture this proportion by assuming an $F$ of 1.5. However, $s f$ housing often uses more land for gardens instead of floor space relative to the $m f$ sector, implying $F>1.5$.

\footnotetext{
${ }^{10}$ Owner-occupied housing could be dealt with by modeling user costs rather than rents. However, in that case we would need to take into account the wealth effect of house price changes (capital gains), which can be ignored in the standard setting with absentee landowners.

${ }^{11}$ Suppose this is not the case. If the bid rents for both types of housing would be the actual prices for floor space, the budget line for $m f$ housing would lie entirely below that for $s f$ housing. With the indifference curve referring to $m f$ housing lying entirely above that for $s f$ housing the consumer would be unable to reach the given utility level on which the bid rents are based in both dwelling types. This implies a contradiction.
} 
Profits per square unit of land, $\pi_{i}$, are given by either $\pi_{m f}=F \Psi(u, x, y, m f)-C_{m f}-p_{l}$ or $\pi_{s f}=\Psi(u, x, y, s f)-C_{s f}-p_{l}$, where $p_{l}$ denotes the land rent and $C_{m f}$ and $C_{s f}$ the (annualized) construction costs per square unit of land. While this is not strictly necessary for our model, it is conventional to assume that $C_{m f}>C_{s f .}{ }^{12}$ Setting these profits to zero, we obtain the bid rent functions for land:

$$
\begin{aligned}
& \Pi(u, x, y, s f)=\Psi(u, x, y, s f)-C_{s f}, \\
& \Pi(u, x, y, m f)=F \Psi(u, x, y, m f)-C_{m f} .
\end{aligned}
$$

Developers choose floor sizes optimally, implying that they choose the floor sizes that solve the consumer problem (1).

Whether $m f$ or $s f$ units are constructed is determined by the highest bid; $m f$ units are built when $\Pi(u, x, y, m f)>\Pi(u, x, y, s f)$, or:

$$
\Psi(u, x, y, m f)>\frac{\Psi(u, x, y, s f)-C_{s f}+C_{m f}}{F} .
$$

We would expect to see $m f$ housing close to the city center and single-family housing in the suburban ring around the center. This pattern emerges when inequality (4) is satisfied in the center and when, at the intersection of the two sectors, the bid rent curve for land in $m f$ housing is steeper than the bid rent curve for land in $s f$ housing, or equivalently, when the profits associated with the construction of $m f$ housing decrease faster than the profits associated with the construction of $s f$ housing:

$$
\frac{\partial \Pi(u, x, y, m f)}{\partial x}<\frac{\partial \Pi(u, x, y, s f)}{\partial x} .
$$

To provide some intuition for this condition, we substitute the expressions for bid rents for floor space (1) into condition (5), and use the 'Muth condition' that $\partial \Psi(u, x, y, i) / \partial x=-t / s_{i}$. We can now rewrite this condition as $F / s_{m f}>1 / s_{s f}$. Hence, (5) is equivalent to the requirement that the household density in the area with $m f$ housing adjacent to the boundary between the two sectors exceeds the corresponding density in the area that contains the $s f$ housing. If we assume that this mild condition holds, multi-family housing will be nearer to the center and single-family housing nearer to the edge of the city. In what follows we assume (4) and (5) to be true.

Figure 1 illustrates bid rents for floor space and land in both sectors as a function of distance to the CBD. The black line is the bid rent curve for land. To the left of $x^{*}$, which is the distance that solves expression (4) with equality, this land is used for construction of $m f$ units and between $x^{*}$ and $x^{b}$ it is used for construction of $s f$ units. The urban fringe $x^{b}$ is determined by the condition that land in $s f$ housing is equally valuable as land in agricultural use. Note that the bid rent curve for land is steeper to the left of $x^{*}$ than to the right of it. The grey line

\footnotetext{
${ }^{12}$ The extended model discussed in Appendices B and C makes the realistic assumption that the construction cost per unit of land is convex in the number of floors.
} 
between $x^{*}$ and $x^{b}$ is the bid rent for floor space in $s f$ units, it equals the bid rent for land plus the costs of constructing floor space in this sector. To the left of $x^{*}$, the bid rent for floor space (of $m f$-type) drops. This is because it is inferior to floor space in $s f$ units. Yet land is more profitable in this usage as unit density jumps up by a sufficient amount.

Figure 1: Bid rent functions for floor space and land

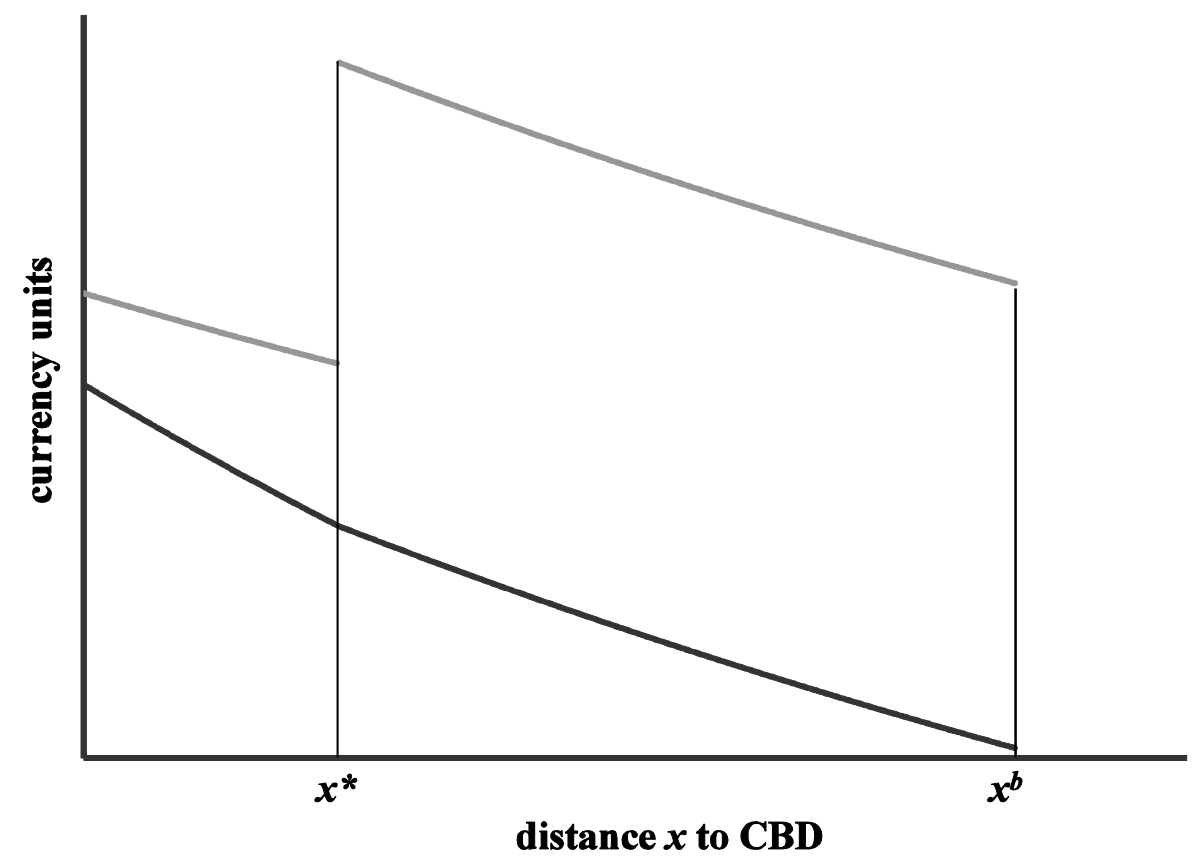

Figure 2 illustrates the effect of an increase in local income: all bid rent curves are shifted outwards by the same amount, and hence, the boundary between the $m f$ and $s f$ sectors and the urban fringe shift outwards by this amount as well. More precisely, if income rises by an amount $\Delta y$, then bid rents shift outward by an amount $\Delta y / t$. This is seen for the bid rents for floor space by revisiting expression (1):

$$
\begin{aligned}
& \Psi(u, x+\Delta y / t, y+\Delta y, i)=\max _{s} \frac{y+\Delta y-t(x+\Delta y / t)-z(u, s, i)}{s} \\
& =\quad \Psi(u, x, y, i),
\end{aligned}
$$

and a similar derivation can be made for bid rents for land in expressions (3a) and (3b). As a consequence, the nature of new housing supply in terms of type and floor space shifts outwards from the CBD by an amount $\Delta y / t$ as well. 


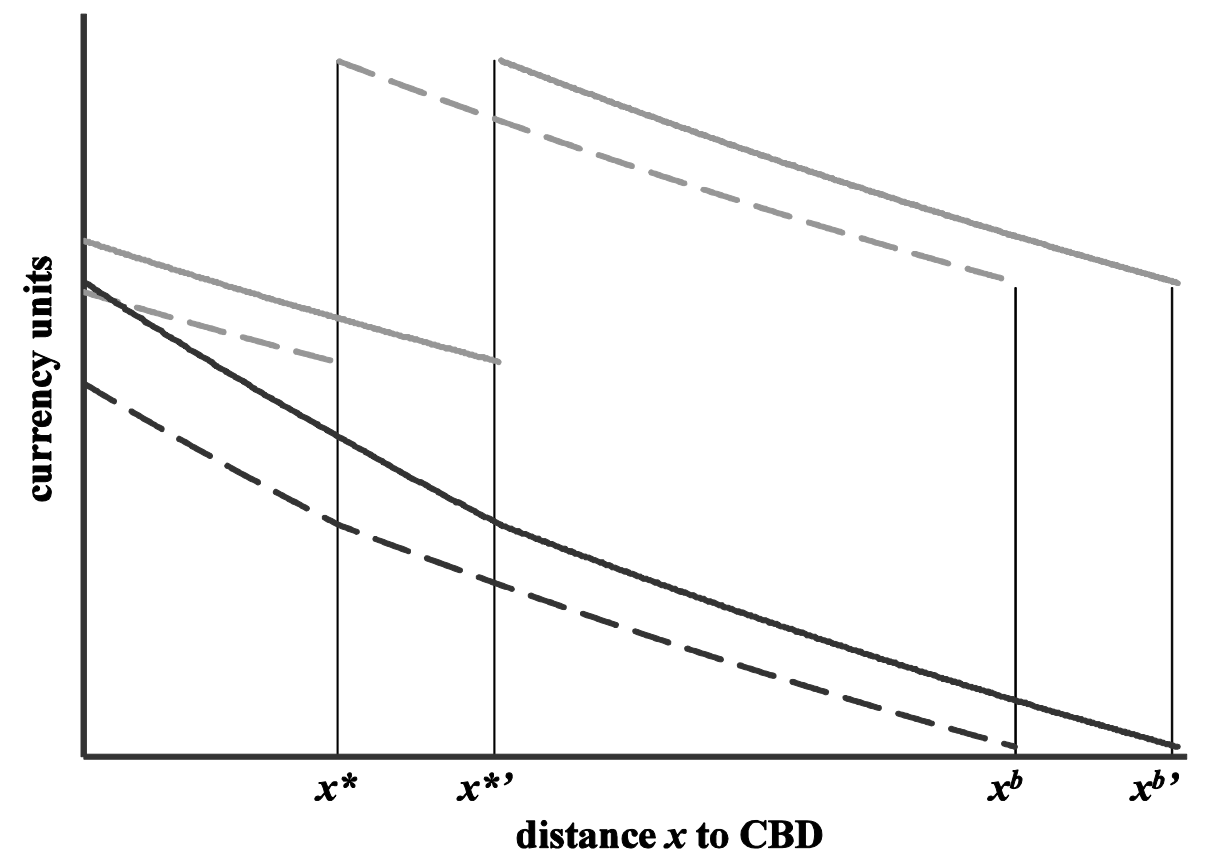

\section{Conversion rates and testable predictions}

In this subsection we derive predictions about the nature of new housing supply in situations where housing construction takes place everywhere in the city, consistent with stylized facts from the AHS and empirical evidence discussed in Section 2. For ease of exposition we assume that in the part of the city where $m f$ housing is constructed, a percentage $\alpha_{m f}$ of all land (developed or open and developable) is converted into new housing in each period, while in the part of the city where $s f$ housing is constructed a percentage $\alpha_{s f}$ of all land is converted into new development in each period. The new development can be thought of as either redevelopment of defunct housing stock or as construction of new housing on greenfield or brownfield land. ${ }^{13}$ The two percentages $\alpha_{s f}$ and $\alpha_{m f}$ may be different, and in particular $\alpha_{s f}$ may be larger than $\alpha_{m f}$, as suggested by the empirical evidence discussed in Section 2.

We assume that the conversion rates $\alpha_{i}(i=m f, s f)$ are increasing functions of local income $y$ : $\alpha_{i}=\alpha_{i}(y)$. The rationale for this assumption is that the opportunity cost of keeping the land open or in the existing (no longer-optimal) use increases with income. We further assume that $\alpha_{i}$ is always positive, which means that there will always be some new construction, even if local income (growth) is below the national income (growth). This assumption is consistent with stylized facts; there has been some new construction of $m f$ and $s f$ housing even during Detroit's worst crisis period.

\footnotetext{
${ }^{13}$ The conversion rate can be defined formally as the amount of land that is either developed or redeveloped in a certain area in each period relative to the total amount of all land (developed and open and developable) in the area, both at a given distance from the CBD. So the denominator does not distinguish between open land, already developed land (with depreciating capital), or brownfield land. In reality, more redevelopment or brownfield development takes place in more central locations. In our model, since empirically we cannot distinguish between redevelopment and development of open land, we are only interested in the nature of new housing supply. Hence, in our model there is also no need to distinguish between the fraction $\alpha_{i}$ that is due to redevelopment of depreciated stock or due to new development of open land.
} 
We impose that a local income shock brings about the same percentage change in the conversion rate for both types of housing, i.e. $\alpha_{m f}(y)=k \alpha_{s f}(y)$ for some positive constant $k$. This is consistent with the possibility that, when $k$ is markedly smaller than 1 , the additional amount of land that is converted increases much more for $s f$ housing than for $m f$ housing. For example, if $k=2 / 3$ and a given income shock increases $\alpha_{m f}$ from 2 to 3 percent, the corresponding $\alpha_{s f}$ increases from 3 to 4.5 percent. Since the outer ring of the city where $s f$ construction occurs has a significantly larger surface area, in this example, the total amount of new construction of $s f$ housing (in terms of land area) would far exceed that of $m f$ construction. The assumption of a positive constant $k$ has the advantage that it keeps the model tractable and provides a simple benchmark case.

The empirical evidence discussed earlier suggests that $k<1$. This is consistent with theoretical reasoning: Since more central locations are more developed than more remote ones and since $m f$ housing requires larger sites, fewer suitable parcels of open land will typically be available for construction of $m f$ housing. Thus, building new tall apartment blocks in central locations normally implies redevelopment of depreciated properties rather than development on an open plot of land. Such redevelopment is typically highly involved - much more complex and costly than (re-)development of low density $s f$ housing in more peripheral locations.

With $k<1$ there will be a discontinuity in the conversion rate, which arises by assumption, at the boundary $x^{*}$ (i.e., $\alpha_{m f}<\alpha_{s f}$ ). The discontinuity in the conversion rate implies that a positive local income shock extends the part of the city where the conversion rate is comparably lower, that is, where $m f$ housing is constructed (i.e., the boundary between the $m f$ and the $s f$ sector shifts outwards). To the extent that the conversion rate does not drop in the part of the city where the local income shock causes a change in the predominant housing type (from $s f$ to $\mathrm{mf}$ ) but instead remains constant or increases, the positive impact of a positive income shock on the share of new $m f$ housing construction will be understated (i.e., Prediction 1 below holds a fortiori).

We take the city as it has been developed in previous periods as given and consider what happens in a single period, say period 1, when the local income level is $y$ and utility, which is determined at the national level, is $u^{*}$. If local income had grown at the national average, its value would be $y^{*}$. In what follows we refer to the situation, in which $y>y^{*}$ as a local increase in income (holding national income constant).

Let $N_{i}(y)$ denote the number of newly built units of type $i$ when local income equals $y$. The quantity $N_{i}(y)$ is computed by multiplying the unit density that solves the consumer problem in (1) with the amount of newly converted land at each distance from the CBD, and then integrating this product over $x$. Our first prediction about the composition of new urban housing supply can be expressed as:

Prediction 1: A local increase in income, holding national income constant, raises the share of mf units in new construction. More formally; $y>y *$ implies: 


$$
\frac{N_{m f}(y)}{N_{m f}(y)+N_{s f}(y)}>\frac{N_{m f}\left(y^{*}\right)}{N_{m f}\left(y^{*}\right)+N_{s f}\left(y^{*}\right)}
$$

and an analogous implication holds for the opposite inequality.

Proof. See Appendix C.

We already discussed the intuition for this result above: a rise in local income pushes up land prices everywhere in the city, which in turn leads to substitution away from land in the housing production process. This also implies that the amount of floor space in newly constructed units decreases with local income. At the aggregate city level, this will be the case if the number of newly constructed units increases more strongly than the amount of land devoted to these new units. To state this formally, let $A_{i}(y)$ denote the amount of land converted to use for new construction of units of type $i$ when income rises from $y_{0}$ to $y$. The average amount of floor space in newly built units in the $m f$ and $s f$ sector is then given by $\bar{s}_{m f}(y)=F A_{m f}(y) / N_{m f}(y)$ and $\bar{s}_{s f}(y)=A_{s f}(y) / N_{s f}(y)$. We can express our second prediction as:

Prediction 2: A local increase in income, holding national income constant, lowers the average amount of floor space in newly built units of both types. More formally; $y>y^{*}$ implies:

$$
\bar{s}_{i}(y)<\bar{s}_{i}\left(y^{*}\right)
$$

and an analogous implication holds for the opposite inequality.

Proof. See Appendix C.

Convexities of the bid rent curves and of the land price curves imply that as these curves shift outwards after a rise in local income, the resulting increase in land prices is larger in more central locations, which are the locations where $m f$ construction takes place. Hence, we would expect substitution processes in housing production to be stronger in this sector. However, we cannot prove that this property necessarily follows from the assumptions made thus far and we therefore formulate it as a conjecture:

Conjecture: A local increase in income, holding national income constant, lowers the average amount of floor space in newly built mf units more strongly than in newly built sf units. More formally; $y>y *$ implies:

$$
\frac{\bar{s}_{m f}(y)}{\bar{s}_{m f}\left(y^{*}\right)}<\frac{\bar{s}_{s f}(y)}{\bar{s}_{s f}\left(y^{*}\right)}
$$

and an analogous implication holds for the opposite inequality.

To offer concrete support for this conjecture we carried out a simulation exercise, employing parameter values for the Boston metropolitan area, provided by DiPasquale and Wheaton (1996). DiPasquale and Wheaton demonstrate that population density as a function of distance to the CBD may be accurately described with an exponential density function. For 1990 , the population density is estimated to decrease with $9 \%$ per mile and the intercept of the 
density function is 8.8 . Furthermore, roughly $75 \%$ of an imaginary circle around the CBD is urban land, and the rest is sea. Assuming an exponential density function with these parameters, we can compute the boundaries $x^{*}$ and $x^{b}$ in such a way that the total population in the area is 3.86 million people, as reported by DiPasquale and Wheaton, and that $50 \%$ of all units is $m f$, as reported in the 1993 metro AHS. This yields a boundary between the $m f$ and $s f$ sectors at 15 miles from the CBD and an urban fringe at 30 miles from the CBD. DiPasquale and Wheaton show that the large majority of the residential development in their data is located within 30 miles from the CBD. Hence, his approach appears to generate sensible results. These assumptions suffice to verify that our Conjecture holds by a wide margin. Hence, we investigate its validity in our empirical analysis as well.

\subsection{The role of land use regulation}

Our predictions about the nature of new housing supply were derived under the assumption of competitive land and housing markets. However, many metropolitan areas in the US are subject to tight land use controls. Land use zoning determines where new housing can be built. Zoning and other types of building controls also affect the nature of new supply (e.g., single-family versus multi-family zones; minimum lot size restrictions; caps on density; permissions to subdivide existing units). All these factors drive a wedge between the pure market outcome and the effective 'political-economy' outcome. For example, in regulated markets, floor sizes of new housing units are likely no longer the outcome of bid rent optimization, as in the consumer problem (1). Similarly, restrictions on the construction of $m f$ housing overrule the outcome of the producer problem, in which $x^{*}$ is determined according to the highest and best use (i.e., that use that produces the highest value for a property). Finally, land use restrictions may also affect the long-run supply curve of residential land (Green et al., 2005; Hilber and Vermeulen, 2014; Quigley and Raphael, 2005; Saiz, 2010). As a consequence, our predictions may no longer hold in metro areas that are severely regulated.

This breakdown is illustrated in Figure 3 for the case of a restriction that rules out $m f$ construction beyond $x^{*}$, the fringe between the $m f$ and $s f$ segments before the change in income. The restriction is indicated by the bold vertical line. The continuous black line indicates land rents before the income change - it is identical to the continuous black line in Figure 1. The black and grey dashed lines indicate bid rents for land in $m f$ and $s f$ use respectively after the income change. Since developers do not have the possibility to allocate land to its highest and best use, prices drop at $x^{*}$.

The rise in land rents in the $m f$ segment will induce a reduction in average floor size, so that the number of newly constructed $m f$ units will rise after a positive income shock. However, it rises by less than in the case without the restriction, since the amount of land that is attributed to new $m f$ construction is smaller. After the income shock, the number of newly constructed $s f$ units rises as well, and it rises by more than in the case without the restriction. Hence, it is not clear anymore whether Prediction 1 still holds. Prediction 2 would still seem to apply in this case; floor sizes are lower, in particular in the $m f$ sector. However, in cities where local planning boards impose restrictions on conversion of land to the $m f$ sector, minimum lot size restrictions may also be present. The latter would render Prediction 2 ambiguous as well. 
Hence, in cities with relatively tight land use regulation, little can be said about the impact of local income shocks on the composition of new construction.

Figure 3: Restrictions on rezoning to the mf sector

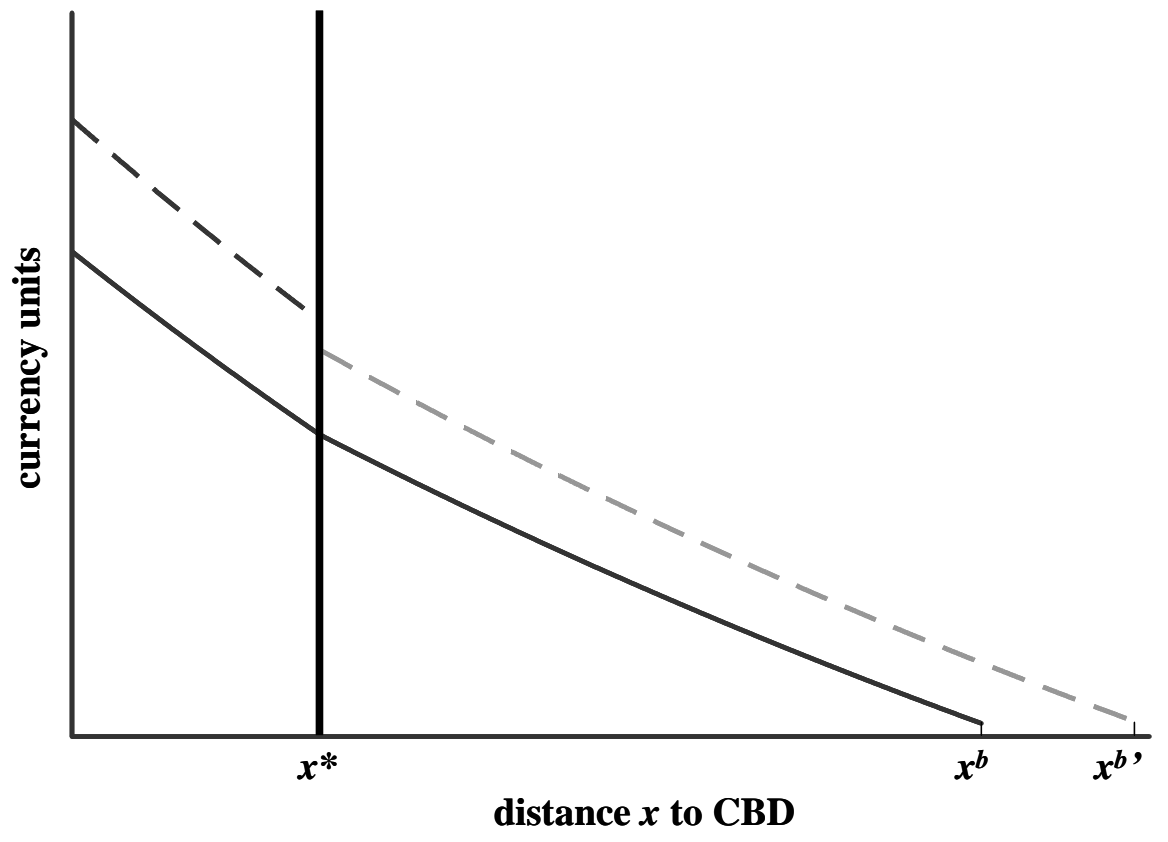

\section{Data, empirical strategy, and baseline specification}

\subsection{The data}

Our data comes from the AHS metropolitan area datasets for the years 1984 to 2004, obtained through HUD User. The US Census conducted these AHS metro surveys annually between 1984 and 1993 and at irregular dates after that. In each year, a different set of MSAs was surveyed. In total, we have information for 47 MSAs and the average number of times that an MSA is surveyed is 3.6. See Appendix Table A1 (in Appendix D) for a list of all MSAs and the years they were surveyed in the AHS. For our period of observation, definitions of the variables of interest were overall consistent, though a few minor adjustments had to be made. $^{14}$

Our main measure of local economic conditions, the MSA-level income per capita, is derived from the Regional Economic Information System of the BEA. ${ }^{15}$ From this dataset we also construct a proxy for construction wages by dividing total earnings in the construction industry by employment. The County Business Patterns (CBP) dataset provides employment data. We use this data to generate two additional variables: the employment growth in the MSA and a measure indicating a labor demand shock (our instrument to identify employment growth). In computing this labor demand shock variable we follow Saks (2008), using the same underlying data and methodology.

\footnotetext{
${ }^{14}$ In 1984, variable definitions changed significantly compared to earlier years. This prevented us from going back further in time. 2004 was the latest available AHS-metro year at the point of data collection.

${ }^{15}$ In our baseline estimates we use income per capita rather than wages as our proxy for local economic conditions. This is because income per capita arguably more fully captures demand side shocks in the housing market. However, as a robustness check (not reported), we replicated our analysis using wages (derived from the County Business Pattern) and our findings are essentially unchanged.
} 
Finally, in order to distinguish MSAs with more stringent land use controls from those with less stringent ones, we use two indices of regulatory restrictiveness. The first index, developed by Saks (2008) is the simple average of six independent surveys conducted during the late 1970s and the 1980s. The method of index construction and the underlying surveys are described in detail in Saks (2008). The second index, the Wharton Residential Land Use Regulatory Index (WRLURI), is derived from a survey conducted during the early 2000s (see Gyourko et al., 2008, and Saiz, 2010, for details). Both indices aggregate information on many different types of land use regulation at the level of municipalities. Since our data spans the period from the early 1980s up to the early 2000s, we create a new 'combined index' by averaging the Saks and WRLURI indices and we proceed by using this combined index in our empirical analysis. ${ }^{16}$ We note however that our results remain virtually unchanged if we use either the Saks index or the WRLURI instead of the combined index.

\subsection{Empirical strategy, measures of new housing supply, and panel dataset}

Our aim is to estimate, at the MSA-level, the impact of local economic conditions on the nature of new housing supply. We do this by regressing MSA-level measures of the type and size of newly built housing units on local income - our focal explanatory variable - and local construction wages. We include the latter variable as a control, to disentangle the effect of our focal variable from labor cost-induced changes in construction costs. The MSA-level measures that capture the type and size of newly built units are derived by averaging each characteristic over the MSA, year of construction, and year of observation (i.e., the survey year). Specifically, we aggregate up the following housing unit level measures from the AHS metro surveys: (1) an indicator that equals 1 if the unit is of the $m f$ type and 0 otherwise, (2) the unit square footage if the unit is of the $m f$ type, and (3) the unit square footage if the unit is of the $s f$ type. Formally, we compute:

$$
M_{t \times M S A \times \tau}^{l}=E\left(M_{h}^{l} \mid t, M S A, \tau\right),
$$

where $M_{h}^{l}$ is the value that variable $M^{l}(l=1,2,3)$ takes for housing unit $h$. We compute the expected value of this variable, for houses that are built in year $\tau$ and observed in an AHS survey of MSA in year $t$.

To illustrate our computation procedure, consider the share of housing built in Boston in 1994 that is of the $m f$ type. First, we construct a dummy variable that is equal to one if a housing unit $h$ is of the $m f$ type (as defined in the AHS) and zero otherwise. The AHS metro sample for Boston in year $t=1998$ (the earliest year after 1994 with a survey for Boston) provides us with information about the characteristics of a sample of housing units in this MSA, as well as the year in which these units were built. Hence, the value of this measure for $\tau=1994$ can be obtained by averaging the dummy variable over all housing units in this 1998-sample that were built in 1994. In this particular example, we assume that the housing units that were constructed in 1994 and observed in 1997, did neither change their type nor their square footage during the three year time window.

\footnotetext{
${ }^{16}$ For two MSAs we do not observe the Saks index. We use instead the WRLURI. For one MSA we do not observe the WRLURI. For this MSA we use instead the Saks index. Thus we can assign a regulatory restrictiveness measure to each MSA in our sample.
} 
The assumption that housing characteristics do not change between the year of construction $\tau$ and the year $t$ in which the unit is observed in the AHS survey, is essential to our identification strategy. To ensure that we do not include any housing units that converted from $m f$ to $s f$ housing and vice versa, we drop all units, for which the AHS reports the construction year $\tau$ as a period of several years. This is the case for older houses; units that were built two decades or more before they are observed in the AHS. We maintain that conversions of units that are younger than 20 years are extremely rare.

Expansions of existing units - especially of $s f$ housing - during renovations are more common. However, it would appear to be highly unlikely that such changes in unit size occur during the first ten or even fifteen years after construction. Hence, we include housing units in our analysis if the gap between $t$ and $\tau$ is 10 years or less. In a robustness check, reported below, we narrow down this window further to 5 years and we also apply a time window of 10 years and 5 years, respectively, to compute the share of $m f$ housing.

By computing measures of the nature of new housing supply according to (10) and subject to the conditions discussed above, we ultimately obtain a panel dataset in which the year of construction $\tau$ constitutes the time dimension and the cluster identifiers are AHS wave-MSA combinations $t \times M S A$. Table 1 provides descriptive statistics of the resulting panel dataset. Apart from reporting the standard descriptive statistics (mean and standard deviation), we decompose the standard deviation into within and between cluster dimensions. This is relevant for our purposes because all estimates that are reported in the subsequent section are identified on variation within clusters only. Table 1 also reports overall minima and maxima, the number of clusters, and the number of observed cells.

As indicated in Panel A of Table 1, $167 t \times M S A$ combinations are observed. The means in this panel are sensible and generally straightforward to interpret. 29.8 percent of newly constructed units are part of a $m f$ structure. Units in the $s f$ sector are on average significantly larger than in the $m f$ sector. The average population size of an AHS-metro area is nearly 3 million, that is, our regression sample consists mainly of large MSAs. The variation of variables is usually larger between than within clusters, particularly for income per capita, population and construction wages. Only for the unit square footage of $m f$ housing the variation within is larger than between clusters. Panels B and C of Table 1 document the descriptive statistics of our three measures characterizing the nature of new housing supply for the subset of MSA-cells, in which land use regulation is less restrictive or more restrictive than in the average cell. The mean of the three measures is similar for the sub-groups.

\subsection{Econometric baseline model}

Our main results are derived from the following specification:

$$
M_{t \times M S A \times \tau}^{l}=C_{t \times M S A}+D_{\tau}+\beta_{1} \log \left(Y_{M S A \times(\tau-1)}\right)+\beta_{2} \log \left(W_{M S A \times(\tau-1)}\right)+\varepsilon_{t \times M S A \times \tau},
$$

where $C_{t \times M S A}$ is a fixed effect that is specific to each MSA and to the year $t$ in which it was surveyed in the AHS, $D_{\tau}$ is a time fixed effect that is specific to the construction year $\tau$, $Y_{M S A x(\tau-1)}$ is the one-year-lagged per capita income, and $W_{M S A x(\tau-1)}$ is the one-year-lagged wage level in the construction industry - a proxy for construction costs. The one year lag in the 
latter two variables can be expected to capture the natural planning/development lag in the construction process. (We experimented with alternative lags and discuss the findings of these robustness checks below.)

Most metropolitan areas are surveyed several times between 1980 and 2004 (see Table A1 in Appendix D for details), and for each time they appear in the AHS, we enter a separate fixed effect. These fixed effects control fully for all time-invariant heterogeneity at the MSA-level and for any heterogeneity across different AHS samples for the same MSA. The year fixed effects, $D_{\tau}$, control for all national level economic shocks at the time of construction. Hence, we can interpret the estimated coefficient $\beta_{1}$ as the impact of local income, holding nationallevel income constant. All remaining heterogeneity is absorbed by the error term $\varepsilon_{t \times M S A \times \tau}$. In the estimation of (11), we account for variation in the number of observations in the AHS on which each $t \times M S A \times \tau$ cell is estimated (and hence the precision of this estimate) by using Weighted Least Squares. ${ }^{17}$ Furthermore, reported standard errors are clustered at the level of $t$ $\times$ MSA cells.

\section{Empirical results}

\subsection{Results for base line specifications}

Table 2 presents results for the base line specification with MSA $\times$ survey year plus construction year-fixed effects as in (11). The dependent variables are the share of $m f$ housing in new construction (column 1) and the log square footage of $s f$ and $m f$ housing (columns 2 and 3). The focal coefficient in column 1 reveals that an increase in local income, holding national level income and unobserved time-invariant characteristics at the MSA-level constant, increases the share of $m f$ housing in new construction, consistent with our Prediction 1. The relationship between one-year-lagged local income and the share of $m f$ housing in new construction is not only highly statistically significant but economically reasonably meaningful: an MSA that receives a one-time positive local income shock that raises local income 10 percent more than that at the national level, all else equal, will observe an increase in the share of $m f$ housing in new construction by 6.4 percentage points. Local wages in the construction industry, interestingly, do not appear to have an independent effect, neither on the share of new $m f$ housing in construction nor on the size of newly built $m f$ or $s f$ units.

Columns 2 and 3 reveal, consistent with our Prediction 2, that an increase in local income, holding national income constant, reduces the floor size of newly constructed housing units, in both the $m f$ and the $s f$ sector. Moreover, the adverse effect is stronger in the $m f$ sector, consistent with the Conjecture, which we formulated in the theory section. An MSA that receives a one-time positive local income shock that raises local income 10 percent more than national level income, all else equal, will observe a reduction in the unit square footage by 4.8 percent in the $s f$ sector and by 16.8 percent in the $m f$ sector, respectively.

Since all our specifications reported in Table 2 include construction year fixed effects, all our effects of local income control for income at the US national level. The construction year

\footnotetext{
${ }^{17}$ Time-varying weights are not allowed in a fixed effects estimator. Hence, we use as weights the number of observations, on which each cell is based, averaged over all observations in the same cluster that are based on at least one AHS observation.
} 
fixed effects (time dummies) themselves reveal trends in the dependent variables at the national level that are unexplained by our other explanatory variables (i.e., by the MSA-level fixed effects and by the local income per capita and construction wage measures). Appendix Table A2 (in Appendix D) reports the suppressed time dummies and reveals that aggregate trends in the dependent variables have been substantial. Notably, conditional on the timevarying and time-invariant local controls, there is a significant and continuous downward trend in the share of $m f$ housing in aggregate construction and a significant upward trend in the unit surface of newly built units, particularly in the $m f$ sector. The effect of raising income appears to have the opposite affect at the national level compared to the local level, consistent with theory.

\subsection{The impact of land use regulation}

Table 3 reports relationships between local income per capita and our three measures that capture the local nature of new housing supply separately for metro areas, in which land use regulation is more (Panel A) and less (Panel B) stringent than the average.

Consistent with our conjectures formulated in Section 3.2, our results strongly indicate that land use regulation mutes the responsiveness of the type and size of new housing supply to local income shocks. The coefficients reported in Panel A of Table 3 reveal that lagged income per capita has no statistically significant effect on the nature of new housing supply in comparably more restrictive US metro areas.

In contrast, in the sample of metro areas with comparably lax land use control (Panel B of Table 3), the estimated effects are consistent with Predictions 1 and 2 and with the Conjecture. Moreover the effects are slightly more pronounced when compared to our baseline estimates for the full sample reported in Table 2. In particular, we find that a $10 \%$ rise in income relative to the national trend is associated with an increase in the share of $m f$ housing by almost 8.8 percentage points (compared to 6.4 percentage points in the baseline specification). Now, we also find a significant negative impact of wages in the construction industry on the share of new $m f$ housing in construction. This could be because building $m f$ housing is more labor intensive compared to $s f$ housing. Overall, the results reported in Table 3 strongly suggest that Predictions 1 and 2 and our Conjecture only hold in metro areas that have comparably lax land use regulation - they do not hold in places with tight control.

\subsection{Are results driven by migration across cities?}

Our empirical findings above are consistent with predictions derived from an open monocentric city model, in which demand for land is fully elastic as a consequence of costless migration across cities. In other words, our underlying theoretical framework suggests that migration is crucial to understanding why positive local income shocks lead to a greater share of construction of $m f$ housing and of smaller units at the local level.

In order to test for the appropriateness of this interpretation of the estimation results, we relate the same measures of the nature of new housing supply to migration rather than income. As is common in the literature (e.g., Blanchard and Katz, 1992 or Saks, 2008), we use employment growth as a proxy for net incoming migration. 
Employment growth (or the net incoming migration) is obviously endogenous. Migration depends not only on demand shocks, but also on the extent to which housing supply accommodates such shocks, as has been recently shown by Glaeser et al. (2006) and Saks (2008). While these studies establish the impact of the housing supply side in terms of the number of newly built units, the same will arguably hold for housing characteristics, as migrants have a comparably strong demand for $m f$ units and small units. This is because migrants tend to have preferences for renting and, as discussed in Section 2, rental units are overrepresented in $m f$ structures.

In order to identify the causal effect of employment growth on our measures that characterize the nature of new housing supply, we use an instrument proposed by Bartik (1991) and applied in empirical work, for example, by Blanchard and Katz (1992), Saks (2008), or Hilber and Vermeulen (2014). Specifically, we instrument for employment growth with a "labor demand shock variable" that equals the weighted average of national industry employment growth rates, where weights are equal to the lagged share of an industry's employment relative to total MSA employment. Intuitively, if an MSA has a large proportion of its jobs in an industry that is doing well at the national level, this MSA is predicted to have a high employment growth rate. The underlying idea is that both national industry specific demand shocks and the lagged industry composition of MSA employment are exogenous to local employment growth.

The results are reported in Table 4. Panel A first reports simple OLS results of the effect of lagged local employment growth on our three measures capturing the nature of new housing supply. The results are qualitatively very similar to those reported in Table 2 for our baseline specification. Next we repeat this exercise but split our sample again into more and less regulated metro areas (Panels B and C). Again, we find strong effects with the expected signs in less regulated metro areas and the effects are again more pronounced than for the full sample. In more regulated areas we find that local employment growth is associated with a decrease rather than an increase in the share of $m f$ housing and this effect is marginally statistically significant. There is no statistically significant effect of employment growth on the size of newly constructed housing units, consistent with our earlier findings and with our theoretical conjectures.

Finally, in Panels D1 and D2 we report the findings of our instrumental variable approach: Panel D1 reports the $2^{\text {nd }}$ stage of our TSLS estimates (along with a test statistic of the strength of the first stage) and Panel D2 reports the corresponding $1^{\text {st }}$ stage results. The results are based on the sample of MSAs with comparably lax land use regulation only. We confine our sample to these MSAs because strict land use controls were demonstrated by Glaeser et al. (2006) and Saks (2008) to also prevent in-migration (i.e., house prices adjust rather than the composition of the housing stock), thus impairing the strength of our identification. ${ }^{18}$ The findings provide support for the proposition that the housing supply adjustments in metro areas with comparably lax land use regulation are driven by migration. Employment growth in these metro areas has a causal positive effect on the share of $m f$ housing in new

\footnotetext{
${ }^{18}$ We also estimated the specifications for the full sample that includes MSAs with strict land use controls. As expected, the results are much less clear-cut.
} 
construction and a causal negative effect on the size of newly constructed housing, consistent with our Predictions 1 and 2. Moreover, the adverse causal effect on the size of new units is more pronounced for $m f$ units, consistent with our theoretical Conjecture.

\subsection{Robustness checks}

We carried out a number of robustness checks. The results are reported in Appendix Tables A3 and A4 (in Appendix D). Table A3 presents estimation results for our baseline model but we assume that the explanatory variables are either contemporaneous or lagged by 2 years. A one year lag seemed most sensible to use given stylized facts about delays imposed by the planning and construction process. However, one could also make a case for a shorter or longer lag. The findings of the sensitivity test suggest that the main effects are robust, although unsurprisingly, they slightly decrease in strength if we use 2-year lagged income per capita.

As discussed in Section 4.2, the assumption that housing characteristics do not change between the year of construction and the year in which the unit is observed in the AHS, is crucial to our identification strategy. In our base specification we include, subject to some constraints, all units to compute the share $m f$ housing and we apply a maximum time window of 10 years for the gap between the year of construction and the AHS survey year for the purpose of computing the $m f$ and $s f$ floor size indices. In Table A4 we report the findings of robustness checks, in which we impose even narrower time windows. Specifically, we check the sensitivity of our results for the share $m f$ measure by introducing a time window and by limiting this to a maximum of 10 years and 5 years (columns 1 and 2), respectively, and we explore the robustness of our findings for the $m f$ and $s f$ floor size measures by limiting the time window to a maximum of 5years (columns 3 and 4). Overall, the main results do not change significantly, even when these narrower windows are applied and the sample sizes, as a consequence, are significantly reduced.

\section{Conclusions}

Local economic conditions have a strong impact on the composition (type and size) of newly constructed housing units in a metro area. When one-year lagged local income rises, controlling for changes in income at the national level, more multi-family units and smaller units are being constructed in a metro area.

The standard urban economic model is a useful starting point for explaining these findings. In an open monocentric city where utility can be considered to be exogenous because of costless migration across cities, rising incomes should lead to higher land prices and therefore a higher capital intensity of land use. In this paper we propose a modified version of the open monocentric city model, in which this effect is brought about through substitution from single-family to multi-family construction and through a reduction of the square footage of dwellings, consistent with our main empirical findings.

Slicing our data with respect to the stringency of land use regulation, we find that the market responses that one would expect on the basis of our theoretical considerations are muted in MSAs with tight land use restrictions. Presumably this is mainly because zoning measures 
that limit development densities prevent that rising local incomes trigger a substitution process towards multi-family structures and smaller units within these structures.

This has implications for the functioning of housing and labor markets alike. Cities in which incomes rise faster than the national trend are likely to attract migrants who exert a demand for temporary rental accommodation until they have decided whether and where to settle more permanently in the city. Rental multi-family structures are arguably the most efficient way to meet these housing needs and in metro areas with lax land use controls, developers are likely to deliver this (profit-maximizing) type of new housing. However, in markets with tight regulation the labor supply response to demand shocks is likely muted and this hampers urban (job) growth in flourishing areas, in line with the arguments put forward by Glaeser et al. (2006) and Saks (2008). While this previous work highlights the fact that regulatory constraints limit the quantity of newly developed housing, our findings suggest that they also hamper adjustment of the housing stock composition. Land use constraints thus create a mismatch in both housing and labor markets and this has particularly adverse effects in flourishing metro areas that struggle to provide suitable housing for would-be-migrants. 


\section{References}

Ahlfeldt, G., Maennig, W., 2013. Homevoters vs. leasevoters: A spatial analysis of airport effects, CESifo Working Paper No. 4301.

Alonso, W., 1964. Location and land use, Harvard University Press, Cambridge.

Bartik, T., 1991. Who Benefits from State and Local Economic Development Policies?, W.E. Upjohn Institute for Employment Research, Kalamazoo, MI.

Baum-Snow, N., Marion, J., 2009. The effects of low income housing developments on neighborhoods, Journal of Public Economics 93(5-6), 654-666.

Blanchard, O., Katz, L., 1992. Regional evolutions, Brookings Papers on Economic Activity 1992(1), 1-75.

Blanchflower, D.G., Oswald, A.J., 2013. Does high home-ownership impair the labor market?, NBER Working Paper No. 19079.

Bracke, P., Hilber, C., Silva, O., 2014. Homeownership and entrepreneurship: The role of mortgage debt and commitment, mimeo, London School of Economics, June.

Brueckner, J.K., 1987. The structure of urban equilibria: a unified treatment of the Muth-Mills model, In: E.S. Mills (ed.) Handbook of Regional and Urban Economics, volume 2, NorthHolland/Elsevier, Amsterdam, pp. 821-845.

Brueckner, J.K., 2000. Urban growth models with durable housing: An overview, In: J.-M. Huriot and J.-F. Thisse (eds.) Economics of cities: Theoretical perspectives, Cambridge University Press, Cambridge, pp. 263-289.

Brueckner, J.K., Rosenthal, S., 2009. Gentrification and Neighborhood Housing Cycles: Will America's Future Downtowns be Rich?, Review of Economics and Statistics 91(4), 725 743.

Burchfield, M., Overman, H.G., Puga, D. and Turner, M.A., 2006. Causes of sprawl: a portrait from space, Quarterly Journal of Economics 121(2), 587-633.

Capozza, D.R, Helsley, R.W., 1990. The Stochastic City, Journal of Urban Economics 28, 187-203.

Coulson, N.E., Fisher, L.M., 2014. Houses, Apartments and Condos: The Governance of Multifamily Housing, mimeo, Penn State University, January.

Dietz, R.D., Haurin, D.R., 2003. The social and private micro-level consequences of homeownership, Journal of Urban Economics 54, 401-450.

DiPasquale, D., 1999. Why don't we know more about housing supply?, Journal of Real Estate Finance and Economics 18, 9-23.

DiPasquale, D., Glaeser, E.L., 1999. Incentives and social capital: Are homeowners better citizens?, Journal of Urban Economics 45(2), 354-384.

DiPasquale, D., Wheaton, W.C., 1996. Urban Economics and Real Estate Markets, Prentice Hall, Englewood Cliffs, NJ. 
Duranton, G., Puga, D., 2014. The growth of cities, In: Philippe Aghion and Steven N. Durlauf (eds.) Handbook of Economic Growth, volume 2, Elsevier, Amsterdam, 781-853.

Fischel, W., 2000. Zoning and land use regulations, In: Bouckaert Boudewijn and Gerrit De Geest (eds.) Encyclopedia of Law and Economics, volume 2, Edward Elgar, Cheltenham, pp. 403-442.

Fischel, W.A., 2001. Homevoters, Municipal Corporate Governance, and the Benefit View of the Property Tax, National Tax Journal 54, 157-173.

Fujita, M., 1989. Urban Economic Theory: Land Use and City Size, Cambridge University Press, Cambridge, UK.

Galster, G.C., 1983. Empirical Evidence on Cross-Tenure Differences in Home Maintenance and Conditions, Land Economics 59, 107-113.

Glaeser, E.L., Gyourko, J., 2005. Urban decline and durable housing, Journal of Political Economy 113, 345-375.

Glaeser, E.L., Gyourko, J., Saks, R., 2006. Urban growth and housing supply, Journal of Economic Geography 6, 71-89.

Green, R.K., Malpezzi, S. and Mayo, S.K., 2005. Metropolitan-specific estimates of the price elasticity of supply of housing, and their sources, American Economic Review 95, 334-39.

Gyourko, J., Saiz, A., Summers, A., 2008. A new measure of the local regulatory environment for housing markets: The Wharton Residential Land Use Regulatory Index, Urban Studies 45, 693-729.

Harding, J., Rosenthal, S., 2013. Homeowner-Entrepreneurs, Housing Capital Gains, and Self-Employment, mimeo, Syracuse University.

Hilber, C.A.L., 2005. Neighborhood externality risk and the homeownership status of properties, Journal of Urban Economics 57(2), 213-241.

Hilber, C.A.L., 2014. The determinants of homeownership: Panel data evidence from Europe, mimeo, London School of Economics, July.

Hilber, C.A.L., 2010. New housing supply and the dilution of social capital, Journal of Urban Economics 67(3), 419-437.

Hilber, C.A.L., Mayer, C., 2009. Why do households without children support local public schools? Linking house price capitalization to school spending, Journal of Urban Economics 65(1), 74-90.

Hilber, C.A.L., Robert-Nicoud, F., 2013. On the origins of land use regulations: Theory and evidence from US metro areas. Journal of Urban Economics 75(1): 29-43.

Hilber, C.A.L., Turner, T., 2014. The mortgage interest deduction and its impact on homeownership decisions, Review of Economics and Statistics, forthcoming.

Hilber, C.A.L., Vermeulen, W, 2014. The impact of supply constraints on house prices in England, Economic Journal, forthcoming. 
Hoff, K., Sen, A. 2005. Homeownership, community interactions, and segregation, American Economic Review 95(4), 1167-1189.

Linneman, P., 1985. An economic analysis of the homeownership decision, Journal of Urban Economics 17(2), 230-246.

Mills, E.S., 1967. An aggregative model of resource allocation in a metropolitan area, American Economic Review 57, 197-210.

Mills, E.S., 1972. Urban Economis, Scott Foresman, Glenview, Illinois.

Muth, R.F., 1969. Cities and Housing, University of Chicago Press, Chicago.

McDonald, J.F. and D.P. McMillen. 2000. Employment Subcenters and Subsequent Real Estate Development in Suburban Chicago, Journal of Urban Economics 48, 135-157.

Ortalo-Magné, F., Prat, A., 2014. On the Political Economy of Urban Growth: Homeownership versus Affordability, American Economic Journal: Microeconomics 6(1), 154-181.

Oswald, A., 1996. A conjecture on the explanation for high unemployment in the industrialised nations: Part 1. Warwick Economic Research Papers.

Quigley, J.M. and Raphael, S., 2005. Regulation and the high cost of housing in California, American Economic Review 95, 323-28.

Rosenthal, S., 2008. Old homes, externalities, and poor neighborhoods: A dynamic model of urban decline and renewal, Journal of Urban Economics 63(3), 816-840.

Saiz, A., 2010. The geographic determinants of housing supply, Quarterly Journal of Economics 125(3), 1253-1296.

Saks, R.E., 2008. Job creation and housing construction: Constraints on metropolitan area employment growth, Journal of Urban Economics 64, 178-195.

Turner, M.A., 2005. Landscape preferences and patterns of residential development. Journal of Urban Economics 57(1), 19-54. 


\section{TABLES}

Table 1

Metro area-level summary statistics

\begin{tabular}{|c|c|c|c|c|c|c|c|c|}
\hline$\underline{\text { Variable }}$ & Obs. & Mean & Std. Dev. & Between & Within & Min & Max & Clusters \\
\hline \multicolumn{9}{|l|}{ A. Full sample - no metro-dimension } \\
\hline Share multi-family $(m f)$ units & 1829 & 0.298 & 0.169 & 0.127 & 0.118 & 0 & 0.939 & 167 \\
\hline Unit square footage, $s f$ & 1548 & 2453 & 427 & 328 & 288 & 900 & 4500 & 167 \\
\hline Unit square footage, $m f$ & 1513 & 2093 & 1001 & 699 & 745 & 340 & 5000 & 167 \\
\hline Income per capita (p.a.) & 1829 & 17855 & 6448 & 6377 & 3623 & 7616 & 42030 & 167 \\
\hline Employment growth & 1829 & 0.0210 & 0.0241 & 0.0130 & 0.0209 & -0.0619 & 0.103 & 167 \\
\hline Labor demand shock variable & 1829 & -0.0149 & 0.0207 & 0.00772 & 0.0194 & -0.0862 & 0.0426 & 167 \\
\hline MSA population & 1829 & 2872300 & 2956012 & 2937453 & 203213 & 635318 & 17000000 & 167 \\
\hline Wage per employee in construction sector (p.a.) & 1829 & 28597 & 7695 & 7465 & 4296 & 14546 & 56520 & 167 \\
\hline Share of units in sample built between 1969-1979 & 1829 & 0.0689 & 0.253 & 0.0510 & .2495278 & 0 & 1 & 167 \\
\hline Share of units in sample built during 1980s & 1829 & 0.599 & 0.490 & 0.354 & .3697993 & 0 & 1 & 167 \\
\hline Share of units in sample built during 1990s & 1829 & 0.276 & 0.447 & 0.325 & .327798 & 0 & 1 & 167 \\
\hline Share of units in sample built between 2000-2004 & 1829 & 0.0569 & 0.232 & 0.271 & .1281069 & 0 & 1 & 167 \\
\hline Share developed residential land (excl. industrial) & 1829 & 0.142 & 0.104 & 0.102 & 0 & .0327 & 0.501 & 167 \\
\hline Average regulatory restrictiveness & 1829 & 0.142 & 0.714 & 0.714 & 0 & -1.119 & 1.889 & 167 \\
\hline \multicolumn{9}{|l|}{ B. Metro areas with regulatory restrictiveness $<$ average } \\
\hline Share $m f$ units & 918 & 0.285 & 0.165 & 0.120 & 0.121 & 0 & .826 & 83 \\
\hline Unit square footage, $s f$ & 769 & 2436 & 400 & 331 & 247 & 1525 & 4017 & 83 \\
\hline Unit square footage, $m f$ & 749 & 2021 & 987 & 690 & 737 & 403 & 5000 & 83 \\
\hline \multicolumn{9}{|l|}{ C. Metro areas with regulatory restrictiveness $>$ average } \\
\hline Share $m f$ units & 911 & 0.311 & 0.173 & 0.134 & 0.114 & 0 & 0.939 & 84 \\
\hline Unit square footage, $s f$ & 779 & 2469 & 452 & 325 & 324 & 900 & 4500 & 84 \\
\hline Unit square footage, $m f$ & 764 & 2163 & 1009 & 701 & 753 & 340 & 5000 & 84 \\
\hline
\end{tabular}


Table 2

Base specifications (weighted fixed effects models, full sample) Dependent variables: Characteristics of newly built housing stock

\begin{tabular}{|c|c|c|c|}
\hline & (1) & (2) & (3) \\
\hline & $\begin{array}{l}\text { Share } m f \\
\text { units }\end{array}$ & $\begin{array}{l}\log \text { (unit sq. } \\
\quad \text { foot, } s f \text { ) }\end{array}$ & $\begin{array}{l}\text { Log (unit sq. } \\
\quad \text { foot, } m f \text { ) }\end{array}$ \\
\hline \multirow{2}{*}{$\begin{array}{l}\text { Log(Personal income per capita), } \\
\text { 1-year lagged }\end{array}$} & $0.640 * * *$ & $-0.484 * *$ & $-1.676^{* * *}$ \\
\hline & $(0.130)$ & $(0.223)$ & $(0.556)$ \\
\hline \multirow{2}{*}{$\begin{array}{l}\text { Log(Construction sector annual wage per } \\
\text { employee), 1-year lagged }\end{array}$} & -0.117 & -0.00942 & 0.208 \\
\hline & $(0.105)$ & $(0.112)$ & $(0.316)$ \\
\hline Metro area $\times$ AHS-year fixed effects & Yes & Yes & Yes \\
\hline Year built-fixed effects ${ }^{\dagger}$ & Yes & Yes & Yes \\
\hline \multirow[t]{2}{*}{ Constant } & $-4.686 * * *$ & $12.58 * * *$ & $22.06 * * *$ \\
\hline & $(0.960)$ & $(1.983)$ & $(4.687)$ \\
\hline Observations & 1829 & 1548 & 1513 \\
\hline Number of AHS-year x metro area combinations & 167 & 167 & 167 \\
\hline \multirow[t]{3}{*}{ R-squared } & 0.242 & 0.178 & 0.063 \\
\hline & 0.307 & 0.047 & 0.0003 \\
\hline & 0.234 & 0.043 & 0.003 \\
\hline
\end{tabular}

Notes: Robust standard errors in parentheses. *** Significant at 1\%; ** significant at 5\%; * significant at $10 \% .{ }^{\dagger}$ Coefficients and robust standard errors of year built-fixed effects are reported in Appendix Table A2 (Appendix D). 
Table 3

More Regulated versus Less Regulated Metro Areas

Dependent variables: Characteristics of newly built housing stock

\begin{tabular}{|c|c|c|c|}
\hline & $(1)$ & $(2)$ & $(3)$ \\
\hline & $\begin{array}{l}\text { Share } m f \\
\text { units }\end{array}$ & $\begin{array}{l}\text { Log (unit sq. } \\
\text { foot, } s f \text { ) }\end{array}$ & $\begin{array}{l}\text { Log (unit sq. } \\
\text { foot, } m f \text { ) }\end{array}$ \\
\hline \multicolumn{4}{|c|}{ Panel A: More regulated metropolitan areas } \\
\hline $\begin{array}{l}\text { Log(Personal income per capita }) \\
1 \text {-year lagged }\end{array}$ & $\begin{array}{r}-0.0336 \\
(0.276)\end{array}$ & $\begin{array}{r}-0.0759 \\
(0.439)\end{array}$ & $\begin{array}{c}0.207 \\
(1.060)\end{array}$ \\
\hline $\begin{array}{l}\text { Log(Construction sector annual wage per employee), } \\
\text { 1-year lagged }\end{array}$ & $\begin{array}{c}0.193 \\
(0.138)\end{array}$ & $\begin{array}{l}-0.161 \\
(0.170)\end{array}$ & $\begin{array}{l}-0.413 \\
(0.442)\end{array}$ \\
\hline Metro area $\times$ AHS-year fixed effects & Yes & Yes & Yes \\
\hline Year built-fixed effects & Yes & Yes & Yes \\
\hline Constant & $\begin{array}{l}-1.296 \\
(2.137)\end{array}$ & $\begin{array}{c}10.19 * * * \\
(3.467)\end{array}$ & $\begin{array}{c}10.16 \\
(8.117)\end{array}$ \\
\hline Observations & 911 & 779 & 764 \\
\hline Number of AHS-year $\mathrm{x}$ metro area combinations & 84 & 84 & 84 \\
\hline R-squared within & 0.217 & 0.184 & 0.085 \\
\hline between & 0.387 & 0.128 & 0.373 \\
\hline overall & 0.271 & 0.102 & 0.151 \\
\hline \multicolumn{4}{|c|}{$\begin{array}{ll}\text { Panel B: Less regulated metropolitan areas } \\
\end{array}$} \\
\hline $\begin{array}{l}\text { Log(Personal income per capita }) \\
\text { 1-year lagged }\end{array}$ & $\begin{array}{c}0.878 * * * \\
(0.142)\end{array}$ & $\begin{array}{c}-0.597 * * * \\
(0.172)\end{array}$ & $\begin{array}{c}-2.509 * * * \\
(0.424)\end{array}$ \\
\hline $\begin{array}{l}\text { Log(Construction sector annual wage per employee), } \\
\text { 1-year lagged }\end{array}$ & $\begin{array}{l}-0.339 * * * \\
(0.127)\end{array}$ & $\begin{array}{l}0.0943 \\
(0.152)\end{array}$ & $\begin{array}{c}0.628 \\
(0.439)\end{array}$ \\
\hline Metro area $\times$ AHS-year fixed effects & Yes & Yes & Yes \\
\hline Year built-fixed effects & Yes & Yes & Yes \\
\hline Constant & $\begin{array}{c}-4.674 * * * \\
(1.273) \\
\end{array}$ & $\begin{array}{c}12.56 * * * \\
(1.824) \\
\end{array}$ & $\begin{array}{c}25.68 * * * \\
(5.110) \\
\end{array}$ \\
\hline Observations & 918 & 769 & 749 \\
\hline Number of AHS-year $x$ metro area combinations & 83 & 83 & 83 \\
\hline R-squared within & 0.334 & 0.237 & 0.107 \\
\hline between & 0.350 & 0.075 & 0.003 \\
\hline overall & 0.281 & 0.074 & 0.015 \\
\hline
\end{tabular}

Notes: Robust standard errors in parentheses. $* * *$ Significant at 1\%; ** significant at 5\%; $*$ significant at $10 \%$. Sample split is based on the mean of an index of regulatory tightness during the late 1970 s / early $1980 \mathrm{~s}$ (Saks, 2008) and during the early 2000s (Gyourko et al., 2008; Saiz, 2010). 
Table 4

Are the Results Driven by Migration? (OLS- and TSLS-Estimates)

\begin{tabular}{|c|c|c|c|}
\hline & $(1)$ & $(2)$ & (3) \\
\hline Dependent variables: & $\begin{array}{c}\text { Share } m f \\
\text { units }\end{array}$ & $\begin{array}{l}\log \text { (unit sq. } \\
\text { foot, } s f \text { ) }\end{array}$ & $\begin{array}{l}\text { Log (unit sq. } \\
\text { foot, } m f \text { ) }\end{array}$ \\
\hline \multicolumn{4}{|c|}{ Panel A: Full sample (OLS) } \\
\hline $\begin{array}{l}\text { Employment growth, } \\
\text { 1-year lagged }\end{array}$ & $\begin{array}{l}0.660 * * \\
(0.309)\end{array}$ & $\begin{array}{l}-0.392 * \\
(0.233)\end{array}$ & $\begin{array}{l}-2.254 * * * \\
(0.779)\end{array}$ \\
\hline $\begin{array}{l}\log (\text { Construction cost sector annual wage per } \\
\text { employee), 1-year lagged }\end{array}$ & $\begin{array}{c}0.150^{*} \\
(0.0764)\end{array}$ & $\begin{array}{l}-0.197 * \\
(0.105)\end{array}$ & $\begin{array}{l}-0.425 \\
(0.282)\end{array}$ \\
\hline Fixed effects and controls & Yes & Yes & Yes \\
\hline Observations & 1829 & 1548 & 1513 \\
\hline R-squared within/between/overall & $0.23 / 0.50 / 0.31$ & $0.17 / 0.15 / 0.11$ & $.060 / .072 / .060$ \\
\hline Number of AHS-year x metro area combinations & 167 & 167 & 167 \\
\hline \multicolumn{4}{|c|}{$\begin{array}{l}\text { Panel B: More regulated metropolitan areas (OLS) } \\
\end{array}$} \\
\hline $\begin{array}{l}\text { Employment growth, } \\
\text { 1-year lagged }\end{array}$ & $\begin{array}{l}-0.675^{*} \\
(0.399)\end{array}$ & $\begin{array}{c}0.394 \\
(0.297)\end{array}$ & $\begin{array}{c}0.636 \\
(1.088)\end{array}$ \\
\hline $\begin{array}{l}\text { Log(Construction cost sector annual wage per } \\
\text { employee), 1-year lagged }\end{array}$ & $\begin{array}{c}0.180 \\
(0.118)\end{array}$ & $\begin{array}{l}-0.195 \\
(0.150)\end{array}$ & $\begin{array}{l}-0.340 \\
(0.355)\end{array}$ \\
\hline Fixed effects and controls & Yes & Yes & Yes \\
\hline Observations & 911 & 779 & 764 \\
\hline R-squared within/between/overall & $0.22 / 0.36 / 0.26$ & $0.19 / 0.13 / 0.10$ & $0.085 / 0.24 / 0.12$ \\
\hline Number of AHS-year x metro area combinations & 84 & 84 & 84 \\
\hline \multicolumn{4}{|c|}{$\begin{array}{ll}\text { Panel C: Less regulated metropolitan areas (OLS) } \\
\end{array}$} \\
\hline $\begin{array}{l}\text { Employment growth, } \\
\text { 1-year lagged }\end{array}$ & $\begin{array}{c}0.979 * * \\
(0.388)\end{array}$ & $\begin{array}{c}-0.769 * * * \\
(0.230)\end{array}$ & $\begin{array}{c}-3.217 * * * \\
(0.850)\end{array}$ \\
\hline $\begin{array}{l}\text { Log(Construction cost sector annual wage per } \\
\text { employee), 1-year lagged }\end{array}$ & $\begin{array}{l}0.00280 \\
(0.114)\end{array}$ & $\begin{array}{l}-0.105 \\
(0.136)\end{array}$ & $\begin{array}{l}-0.365 \\
(0.463)\end{array}$ \\
\hline Fixed effects and controls & Yes & Yes & Yes \\
\hline Observations & 918 & 769 & 749 \\
\hline R-squared within/between/overall & $0.32 / 0.63 / 0.39$ & $0.23 / 0.24 / 0.17$ & $.093 / .0001 / .025$ \\
\hline Number of AHS-year x metro area combinations & 83 & 83 & 83 \\
\hline \multicolumn{4}{|c|}{$\begin{array}{ll}\text { Panel D1: Less regulated metropolitan areas (TSLS, } \mathbf{2}^{\text {nd }} \text { stage) }\end{array}$} \\
\hline $\begin{array}{l}\text { Employment growth, } \\
\text { 1-year lagged }\end{array}$ & $\begin{array}{c}1.614 * * * \\
(0.580)\end{array}$ & $\begin{array}{r}-1.665 * \\
(1.011)\end{array}$ & $\begin{array}{l}-3.539 * \\
(1.925)\end{array}$ \\
\hline $\begin{array}{l}\text { Log(Construction cost sector annual wage per } \\
\text { employee), 1-year lagged }\end{array}$ & $\begin{array}{c}-0.00943 \\
(0.115)\end{array}$ & $\begin{array}{l}-0.103 \\
(0.135)\end{array}$ & $\begin{array}{l}-0.374 \\
(0.459)\end{array}$ \\
\hline Fixed effects ${ }^{2)}$ & Yes & Yes & Yes \\
\hline Observations & 918 & 769 & 749 \\
\hline Number of AHS-year x metro area combinations & 83 & 83 & 83 \\
\hline Kleibergen-Paap rk Wald F-statistic (First-stage F) & 12.79 & 15.68 & 23.93 \\
\hline
\end{tabular}

\begin{tabular}{|c|c|c|c|}
\hline \multicolumn{4}{|c|}{ Panel D2: Less regulated metropolitan areas (TSLS, $1^{\text {st }}$ stage) } \\
\hline Dependent variable: & & $\begin{array}{l}\text { oyment gr } \\
\text {-year lagge }\end{array}$ & \\
\hline Labor demand shock, 1-year lagged & $\begin{array}{l}1.580 * * * \\
(0.442)\end{array}$ & $\begin{array}{l}1.540 * * * \\
(0.389)\end{array}$ & $\begin{array}{l}2.300 * * * \\
(0.470)\end{array}$ \\
\hline $\begin{array}{l}\text { Log(Construction cost sector annual wage per } \\
\text { employee), 1-year lagged }\end{array}$ & $\begin{array}{r}-0.00104 \\
(0.0233) \\
\end{array}$ & $\begin{array}{l}-0.00193 \\
(0.0276)\end{array}$ & $\begin{array}{l}-0.0221 \\
(0.0278)\end{array}$ \\
\hline Centered/uncentered R-squared & 0.104 & 0.083 & 0.144 \\
\hline
\end{tabular}

\begin{tabular}{lccc} 
Centered/uncentered R-squared & 0.104 & 0.083 & 0.144 \\
\hline \hline Notes: Robust standard errors in parentheses. $* * *$ Significant at $1 \% * * *$ significant at $5 \% * *$ significant at
\end{tabular}

10\%. ${ }^{1)}$ Bold variable is endogenous. Excluded instrument is labor demand shock variable. ${ }^{2)}$ Year builtfixed effects and constant are partialled out. 


\section{APPENDICES}

\section{Appendix A: Appendix Figure}

Figure A1

Property Development in New York City by Year of Construction

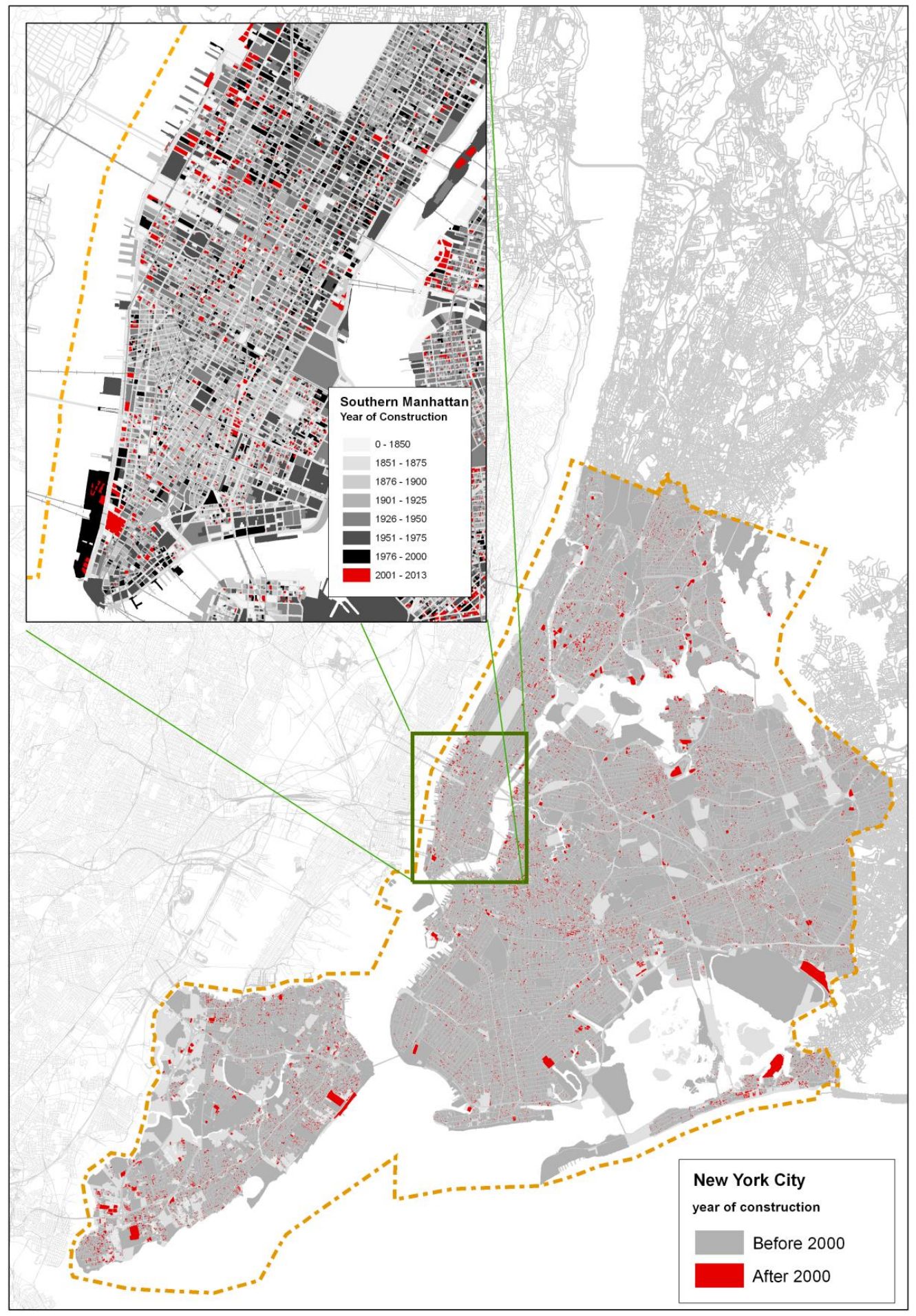




\section{Appendix B: A model with an arbitrary number of dwelling types}

This Appendix introduces an extended version of the model developed in the main text that has an arbitrary number of housing types. That is, we distinguish houses with $F_{1}, F_{2}, F_{3}, \ldots, F_{J}$ floors, with $F_{1}<F_{2}<F_{3}<\ldots<F_{J}$. Houses of type 1 are $s f$, all other types are $m f$. The model of the main text may be interpreted as referring to a situation in which $J=2$ and both types of dwellings are present in the city. Alternatively (and more realistically) it may be interpreted as referring to a condensed version of the present model with an arbitrary number of housing types in which type 1 housing is $s f$ housing and types $2-J$ are aggregated into one single $m f$ housing sector. It may also be argued that this interpretation fits our empirical analysis best, in which we are unable to distinguish between different types of $m f$ housing.

In the two-type model discussed in the main text we have assumed that floor space in $m f$ housing is inferior to floor space in $s f$ housing. In this extension, we also assume that this is the case, however, we further assume that preferences for floor space within the $m f$ sector do not depend on the number of floors in the building, i.e. individuals are indifferent with respect to the height of $m f$ housing. (This is consistent with e.g. the proposition that households dislike noise from their neighbors below, above, and next door. Whether a household lives in say the $4^{\text {th }}$ floor or the $10^{\text {th }}$ floor arguably does not much alter the noise perception.) This implies that bid rent functions for floor space $\Psi(u, x, y, m f)$ are identical for all types of $m f$ housing. Since floor sizes are chosen to optimize this bid rent function (see equation (1)), optimal floor sizes increase monotonously with distance to the CBD.

Developers switch from $F_{i}$ to $F_{i+1}$ if:

$F_{i+1} \Psi(u, x, y, m f)-C_{i+1}>F_{i} \Psi(u, x, y, m f)-C_{i}$,

where $i$ refers to the number of floors. The number of floors of $m f$ housing will be a decreasing step function of the distance to the CBD, if we make the additional assumption that the construction cost per unit of land is convex in the number of floors, i.e. $C_{i+1}-C_{i}$ is increasing in $i$. This assumption seems realistic as higher buildings require more investment in foundations, solid construction materials, or elevators.

The number of housing types available in a city is endogenously determined by bid rents for floor space and construction costs. In larger cities, these bid rents will generally be higher in central areas, so that there is more high-rise construction. As a consequence, it may happen that a new type of housing will be introduced after a positive income shock, or that an existing type will disappear after a negative income shock. For $i>1$, we let $x_{i} *(y)$ denote the boundary between type $i$ and type $i-1$ housing when income equals $y$. For $i=1$ it refers to the boundary of the city. Let $J(y) \leq J$ denote the number of housing types present in the city when income equals $y$. Then the boundaries $x_{i} *(y)$ are defined for dwelling types $1, \ldots, J(y)$.

Finally, the conversion rate in the part of the city where type $i$ dwellings are optimal is $\alpha_{i}(y)$, and we make the proportionality assumption: $\alpha_{i}(y)=k_{i} \alpha_{1}(y)$ for $i=2, \ldots, J$. In practice we expect that $1>k_{2}, \ldots,>k_{J}$, i.e., a higher share of land is converted closer to the urban fringe. 


\section{Appendix C: Proofs of Predictions 1 and 2}

This Appendix proves Predictions 1 and 2 in the more general context of a model with an arbitrary number of floors. Suppose two housing types $i$ and $j, i>j$ are the optimal types for new construction in some sectors of the city when income is $y^{*}$. A sufficient condition for Prediction 1 to hold in this more general model is that when $y>y^{*}$, we have:

$$
\frac{N_{i}(y)-N_{i}\left(y^{*}\right)}{N_{i}\left(y^{*}\right)}>\frac{N_{j}(y)-N_{j}\left(y^{*}\right)}{N_{j}\left(y^{*}\right)},
$$

which says that the additional growth in new type $i$ units caused by a more than average increase in local income exceeds the additional growth in new type $j$ units. If this inequality holds for all $i>1$, i.e. the additional growth in any type $i$ units caused by a more than average increase in local income exceeds the additional growth in new $s f$ (type 1) units, then any weighted average of these growth rates also exceeds the additional growth in new $s f$ units. Hence, prediction 1 continues to hold when we aggregate types $2-J$ into one single category of $m f$ housing, as in the model in the main text.

In order to show that (A2) is valid, we first consider the case where $i<J\left(y^{*}\right)$, i.e. a type of housing that will not be constructed in the city center when $y=y^{*}$. If income in the city equals $y^{*}$, the number of new type $i$ units is given by:

$$
N_{i}(y *)=\alpha_{i}(y *) \int_{x^{*} i_{i+1}\left(y^{*}\right)}^{x_{i}^{*}\left(y^{*}\right)} g_{i}(x, y *) 2 \pi x d x
$$

Where $g_{i}\left(x, y^{*}\right)$ is the density of type $i$ units, i.e. the number of housing units per unit of land. If income rises to $y$, this number equals:

$$
N_{i}(y)=\alpha_{i}(y) \int_{x_{i+1}^{*}(y)}^{x_{*}^{*}(y)} g_{i}(x, y) 2 \pi x d x
$$

Denoting $\Delta y=y-y^{*}$, expression (A4) may be rewritten by using the properties $x_{i} *\left(y^{*}+\Delta y\right)=x_{i} *\left(y^{*}\right)+\Delta y / t$ and $g_{i}\left(x, y^{*}+\Delta y\right)=g_{i}\left(x-\Delta y / t, y^{*}\right)$, which both follow from the fact that income growth shifts the bid rent curve outwards in an open city (see expression (6)). This yields:

$$
N_{i}(y)=\alpha_{i}(y) \int_{x^{*}{ }_{i+1}\left(y^{*}\right)+\Delta y / t}^{x_{i}^{*}\left(y^{*}\right)+\Delta y / t} g_{i}\left(x-\Delta y / t, y^{*}\right) 2 \pi x d x,
$$

Hence, after some manipulation we obtain:

$$
N_{i}(y)=\frac{\alpha_{i}(y)}{\alpha_{i}\left(y^{*}\right)} N_{i}\left(y^{*}\right)+\alpha_{i}(y) \frac{\Delta y}{t} \int_{x^{*} *_{1}\left(y^{*}\right)}^{x_{i}^{*}\left(y^{*}\right)} g_{i}\left(x, y^{*}\right) 2 \pi d x .
$$

The growth in new type $i$ units, triggered by a rise in income from $y^{*}$ to $y$, then follows as: 


$$
\frac{N_{i}(y)-N_{i}\left(y^{*}\right)}{N_{i}\left(y^{*}\right)}=\frac{\alpha_{i}(y)-\alpha_{i}\left(y^{*}\right)}{\alpha_{i}\left(y^{*}\right)}+\frac{\alpha_{i}(y)}{\alpha_{i}\left(y^{*}\right)} \frac{\Delta y}{t} \frac{1}{\hat{x}_{i}}
$$

where:

$$
\hat{x}_{i} \equiv \int_{x^{*}{ }_{i+1}\left(y^{*}\right)}^{x_{i}^{*}\left(y^{*}\right)} x g_{i}\left(x, y^{*}\right) d x / \int_{x^{*}+1}^{x_{i+1}^{*}\left(y^{*}\right)} g_{i}\left(x, y^{*}\right) d x
$$

The value $\hat{x}_{i}$ may be interpreted as the weighted mean of $x$ over the interval $\left[x_{i+1} *\left(y^{*}\right), x_{i} *\left(y^{*}\right)\right]$, where the weighting function is given by $g_{i}\left(x, y^{*}\right)$.

In a similar way, we may derive an expression for the relative increase in construction of type $j$ units if income rises from $y^{*}$ to $y$ :

$$
\frac{N_{j}(y)-N_{j}\left(y^{*}\right)}{N_{j}\left(y^{*}\right)}=\frac{\alpha_{j}(y)-\alpha_{j}\left(y^{*}\right)}{\alpha_{j}\left(y^{*}\right)}+\frac{\alpha_{j}(y)}{\alpha_{j}\left(y^{*}\right)} \frac{\Delta y}{t} \frac{1}{\hat{x}_{j}} .
$$

The first term on the right-hand side of equations (A7) and (A9) is the same for both types, because of the proportionality assumption. However, as units of type $i$ are closer to the CBD than units of type $j$, we must have $\hat{x}_{i}<\hat{x}_{j}$. Thus the validity of inequality (A2) follows.

If $i=J\left(y^{*}\right)$ and type $i$ dwellings start in the CBD, then the additional growth in new type $i$ units caused by a more than average increase in local income can only increase relative to equation (A7), because the inner boundary of the sector where this type is constructed does not have to shift out - it is possible that type $i$ will be constructed in the CBD also if income rises to $y$. Hence, inequality (A2) holds a fortiori.

In order to proof Prediction 2 for the generalized model, we first show that $\bar{s}_{i}(y)>\bar{s}_{i}\left(y^{*}\right)$ for $y^{*}>y$, which is equivalent to:

$$
\frac{N_{i}(y)-N_{i}\left(y^{*}\right)}{N_{i}\left(y^{*}\right)}>\frac{A_{i}(y)-A_{i}\left(y^{*}\right)}{A_{i}\left(y^{*}\right)} .
$$

If the number of new units of type $i$ grows more strongly than the amount of land on which it is built, it must be the case that the average amount of floor space per unit falls.

Again, we start by considering the case $i<J\left(y^{*}\right)$. By definition we have:

$$
A_{i}\left(y^{*}\right)=\alpha_{i}(y *)\left[\pi\left(x^{*}\left(y^{*}\right)\right)^{2}-\pi\left(x^{*}{ }_{i+1}(y *)\right)^{2}\right],
$$

and:

$$
A_{i}(y)=\alpha_{i}(y)\left[\pi\left(x_{i}^{*}(y *)+\frac{\Delta y}{t}\right)^{2}-\pi\left(x *_{i+1}(y *)+\frac{\Delta y}{t}\right)^{2}\right],
$$

where in (A12) we have again made use of the equality $x^{*}(y)=x *_{i}\left(y^{*}\right)+\Delta y / t$. 
We may rewrite this equation as:

$$
A_{i}(y)=\alpha_{i}(y)\left[\frac{A_{i}\left(y^{*}\right)}{\alpha_{i}\left(y^{*}\right)}+2 \pi\left(x^{*}{ }_{i}\left(y^{*}\right)-x^{*}{ }_{i+1}(y *)\right) \frac{\Delta y}{t}\right] .
$$

With some manipulation, it follows that:

$$
\frac{A_{i}(y)-A_{i}\left(y^{*}\right)}{A_{i}\left(y^{*}\right)}=\frac{\alpha_{i}(y)-\alpha_{i}\left(y^{*}\right)}{\alpha_{i}\left(y^{*}\right)}+\frac{\alpha_{i}(y)}{\alpha_{i}\left(y^{*}\right)} \frac{\Delta y}{t} \frac{2}{x^{*}{ }_{i+1}\left(y^{*}\right)+x^{*}{ }_{i}\left(y^{*}\right)} .
$$

Hence, making use of equation (A7), we obtain:

$$
\frac{N_{i}(y)-N_{i}\left(y^{*}\right)}{N_{i}\left(y^{*}\right)}-\frac{A_{i}(y)-A_{i}\left(y^{*}\right)}{A_{i}\left(y^{*}\right)}=\frac{\alpha_{i}(y)}{\alpha_{i}\left(y^{*}\right)} \frac{\Delta y}{t}\left(\frac{1}{\hat{x}_{i}}-\frac{2}{x^{*}{ }_{i+1}\left(y^{*}\right)+x^{*}{ }_{i}\left(y^{*}\right)}\right) .
$$

Inequality (A10) follows because we have:

$$
\hat{x}_{i}<\frac{1}{2}\left(x^{*}{ }_{i+1}\left(y^{*}\right)+x^{*}{ }_{i}\left(y^{*}\right)\right)
$$

Recall that $\hat{x}_{i}$ may be interpreted as the weighted mean of $x$ over the interval $\left[x_{i+1} *\left(y^{*}\right), x_{i} *\left(y^{*}\right)\right]$, where the weighting function is given by $g_{i}\left(x, y^{*}\right)$. If this weighting function were flat, that is the population density would not depend on the distance to the CBD, we would have $\hat{x}_{i}=\left(x_{i+1} *\left(y^{*}\right)+x_{i} *(y *)\right) / 2$. However, it follows from the convexity of the bid rent curve that the housing density function $g_{i}\left(x, y^{*}\right)$ is downward sloping, so that inequality (A16) must hold.

If $i=J\left(y^{*}\right)$ and type $i$ dwellings start in the CBD, then the additional growth in new type $i$ units occurs at a density that is higher than the average for this sector. The area that would have been used for construction of a type with larger building height for types $i<J\left(y^{*}\right)$ consists of the most central locations in the city. Hence, density in this area is higher than anywhere else in this sector. The newly constructed units here can only raise the average density of new construction and inequality (A10) must hold a fortiori.

For prediction 2 to be valid for the aggregate $m f$ sector, we have to show that:

$$
\sum_{i=2}^{J\left(y^{*}\right)} w_{i}\left(y^{*}\right) \bar{s}_{i}\left(y^{*}\right)<\sum_{i=2}^{J(y)} w_{i}(y) \bar{s}_{i}(y)
$$

where $w_{i}(y)$ is the construction weight of type $i$ in total $m f$ construction:

$$
w_{i}(y)=N_{i}(y) / \sum_{j=2}^{J(y)} N_{j}(y)
$$

Inequality (A17) may be rewritten as: 


$$
\sum_{i=2}^{J\left(y^{*}\right)} w_{i}\left(y^{*}\right)\left(\bar{s}_{i}\left(y^{*}\right)-\bar{s}_{i}(y)\right)-\sum_{i=2}^{J(y)}\left(w_{i}(y)-w_{i}\left(y^{*}\right)\right) \bar{s}_{i}(y)<0 .
$$

We have shown above that $\bar{s}_{i}\left(y^{*}\right)<\bar{s}_{i}(y)$ for all $i$ : the average size of apartments of all types decreases. The first term is therefore negative. The second term is also negative since Prediction 1 implies that the $m f$ housing types closest to the CBD (which are also the types with the smallest floor size because of our assumption that households are indifferent to building height) will increase their share in total housing production in response to a positive income shock. The apartment types for which the weight increases are thus smaller than those for which the weight decreases. Since the weights must always add up to one, the changes in the weights must add up to zero and the second term must be negative. 


\section{Appendix D: Appendix Tables}

Table A1

AHS-survey years and included metropolitan statistical areas (MSAs)

\begin{tabular}{|c|c|c|c|c|c|c|c|c|c|c|c|c|c|c|c|c|}
\hline \multirow[b]{2}{*}{$M S A$} & \multicolumn{15}{|c|}{ Survey Year } & \multirow{2}{*}{$\begin{array}{c}\text { Times } \\
\text { surveyed }\end{array}$} \\
\hline & 84 & 85 & 86 & 87 & 88 & 89 & 90 & 91 & 92 & 93 & 95 & 96 & 98 & 02 & 04 & \\
\hline Anaheim-Santa Ana, CA & & & $\mathrm{X}$ & & & & $\mathrm{x}$ & & & & & $\mathrm{x}$ & & $\mathrm{x}$ & & 4 \\
\hline Atlanta, GA & & & & $\mathrm{x}$ & & & & $\mathrm{x}$ & & & & $\mathrm{x}$ & & & $\mathrm{x}$ & 4 \\
\hline Baltimore, MD & & & & $\mathrm{x}$ & & & & $\mathrm{x}$ & & & & & $\mathrm{X}$ & & & 3 \\
\hline Birmingham, AL & $\mathrm{x}$ & & & & $\mathrm{x}$ & & & & $\mathrm{x}$ & & & & $\mathrm{x}$ & & & 4 \\
\hline Boston, MA & & $\mathrm{x}$ & & & & $\mathrm{x}$ & & & & $\mathrm{x}$ & & & $\mathrm{x}$ & & & 4 \\
\hline Buffalo, NY & $\mathrm{x}$ & & & & $\mathrm{x}$ & & & & & & & $\mathrm{x}$ & & $\mathrm{x}$ & & 4 \\
\hline Charlotte, NC & & & & & & & & & & & $\mathrm{x}$ & & & $\mathrm{x}$ & & 2 \\
\hline Chicago, IL & & & & $\mathrm{x}$ & & & & $\mathrm{x}$ & & & & & & & & 2 \\
\hline Cincinnati, OH-KY-IN & & & $\mathrm{x}$ & & & & $\mathrm{x}$ & & & & & & $\mathrm{x}$ & & & 3 \\
\hline Cleveland, $\mathrm{OH}$ & $\mathrm{x}$ & & & & $\mathrm{x}$ & & & & $\mathrm{x}$ & & & $\mathrm{x}$ & & & $\mathrm{x}$ & 5 \\
\hline Columbus, $\mathrm{OH}$ & & & & $\mathrm{x}$ & & & & $\mathrm{x}$ & & & $\mathrm{x}$ & & & $\mathrm{x}$ & & 4 \\
\hline Dallas, TX & & $\mathrm{x}$ & & & & $\mathrm{x}$ & & & & & & $\mathrm{x}$ & & $\mathrm{x}$ & & 4 \\
\hline Denver, $\mathrm{CO}$ & & & $\mathrm{x}$ & & & & $\mathrm{X}$ & & & & $\mathrm{x}$ & & & & $\mathrm{x}$ & 4 \\
\hline Detroit, MI & & $\mathrm{x}$ & & & & $\mathrm{x}$ & & & & $\mathrm{x}$ & & & & & & 3 \\
\hline Fort Worth-Arlington, TX & & $\mathrm{x}$ & & & & $\mathrm{x}$ & & & & & & $\mathrm{x}$ & & $\mathrm{x}$ & & 4 \\
\hline Hartford, CT & & & & $\mathrm{x}$ & & & & $\mathrm{x}$ & & & & $\mathrm{x}$ & & & $\mathrm{x}$ & 4 \\
\hline Houston, TX & & & & $\mathrm{x}$ & & & & $\mathrm{x}$ & & & & & $\mathrm{X}$ & & & 3 \\
\hline Indianapolis, IN & $\mathrm{x}$ & & & & $\mathrm{x}$ & & & & $\mathrm{x}$ & & & $\mathrm{x}$ & & & $\mathrm{x}$ & 5 \\
\hline Kansas City, MO-KS & & & $\mathrm{x}$ & & & & $\mathrm{x}$ & & & & $\mathrm{x}$ & & & $\mathrm{x}$ & & 4 \\
\hline Los Angeles-Long Beach, CA & & $\mathrm{x}$ & & & & $\mathrm{x}$ & & & & & & & & & & 2 \\
\hline Memphis, TN-AR-MS & $\mathrm{x}$ & & & & $\mathrm{x}$ & & & & $\mathrm{x}$ & & & $\mathrm{x}$ & & & $\mathrm{x}$ & 5 \\
\hline Miami-Hialeah, FL & & & $\mathrm{x}$ & & & & $\mathrm{x}$ & & & & $\mathrm{x}$ & & & $\mathrm{x}$ & & 4 \\
\hline Milwaukee, WI & $\mathrm{x}$ & & & & $\mathrm{x}$ & & & & & & & $\mathrm{x}$ & & $\mathrm{x}$ & & 4 \\
\hline Minneapolis-Saint Paul & & $\mathrm{X}$ & & & & $\mathrm{x}$ & & & & $\mathrm{x}$ & & & $\mathrm{x}$ & & & 4 \\
\hline New Orleans, LA & & & $\mathrm{x}$ & & & & $\mathrm{x}$ & & & & $\mathrm{x}$ & & & & $\mathrm{x}$ & 4 \\
\hline New York City, NY & & & & $\mathrm{x}$ & & & & $\mathrm{x}$ & & & & & & & & 2 \\
\hline Newark, NJ & & & & $\mathrm{x}$ & & & & $\mathrm{x}$ & & & & & & & & 2 \\
\hline Norfolk-Newport News & $\mathrm{x}$ & & & & $\mathrm{x}$ & & & & $\mathrm{x}$ & & & & $\mathrm{X}$ & & & 4 \\
\hline Oakland, CA & & & & & & & & & & & & & $\mathrm{x}$ & & & 1 \\
\hline Oklahoma City, OK & $\mathrm{x}$ & & & & $\mathrm{x}$ & & & & $\mathrm{x}$ & & & $\mathrm{x}$ & & & $\mathrm{x}$ & 5 \\
\hline Philadelphia, PA-NJ & & $\mathrm{x}$ & & & & $\mathrm{x}$ & & & & & & & & & & 2 \\
\hline Phoenix, AZ & & $\mathrm{x}$ & & & & $\mathrm{x}$ & & & & & & $\mathrm{x}$ & & $\mathrm{x}$ & & 4 \\
\hline Pittsburgh, PA & & & $\mathrm{x}$ & & & & $\mathrm{x}$ & & & & $\mathrm{x}$ & & & & $\mathrm{x}$ & 4 \\
\hline Portland, OR & & & $\mathrm{x}$ & & & & $\mathrm{x}$ & & & & $\mathrm{x}$ & & & $\mathrm{x}$ & & 4 \\
\hline Providence, RI & $\mathrm{x}$ & & & & $\mathrm{x}$ & & & & $\mathrm{x}$ & & & & $\mathrm{x}$ & & & 4 \\
\hline Riverside-San Bernard & & & $\mathrm{x}$ & & & & & & & & & $\mathrm{x}$ & & $\mathrm{x}$ & & 3 \\
\hline Rochester, NY & & & $\mathrm{x}$ & & & & $\mathrm{x}$ & & & & & & $\mathrm{x}$ & & & 3 \\
\hline Sacramento, CA & & & & & & & & & & & & $\mathrm{x}$ & & & $\mathrm{x}$ & 2 \\
\hline Saint Louis, MO-IL & & & & $\mathrm{x}$ & & & & $\mathrm{X}$ & & & & $\mathrm{x}$ & & & $\mathrm{x}$ & 4 \\
\hline Salt Lake City-Ogden, & $\mathrm{x}$ & & & & $\mathrm{x}$ & & & & $\mathrm{x}$ & & & & $\mathrm{x}$ & & & 4 \\
\hline San Antonio, TX & & & $\mathrm{x}$ & & & & $\mathrm{x}$ & & & & $\mathrm{x}$ & & & & $\mathrm{x}$ & 4 \\
\hline San Diego, CA & & & & $\mathrm{x}$ & & & & $\mathrm{x}$ & & & & $\mathrm{x}$ & & $\mathrm{x}$ & & 4 \\
\hline San Francisco, CA & & $\mathrm{x}$ & & & & $\mathrm{x}$ & & & & $\mathrm{x}$ & & & $\mathrm{x}$ & & & 4 \\
\hline San Jose, CA & $\mathrm{x}$ & & & & $\mathrm{x}$ & & & & & $\mathrm{x}$ & & & $\mathrm{x}$ & & & 4 \\
\hline Seattle, WA & & & & $\mathrm{x}$ & & & & & & & & $\mathrm{x}$ & & & $\mathrm{x}$ & 3 \\
\hline Tampa-Saint Petersburg & & $\mathrm{x}$ & & & & $\mathrm{x}$ & & & & $\mathrm{x}$ & & & $\mathrm{x}$ & & & 4 \\
\hline Washington, DC-MD-VA & & $\mathrm{x}$ & & & & & & & & $\mathrm{x}$ & & & $\mathrm{x}$ & & & 3 \\
\hline Total & 11 & 11 & 11 & 11 & 11 & 10 & 10 & 10 & 8 & 7 & 9 & 17 & 15 & 13 & 13 & 167 \\
\hline
\end{tabular}


Table A2

Base Specifications, Year-Built Dummy Variables

\begin{tabular}{|c|c|c|c|}
\hline & (1) & $(2)$ & (3) \\
\hline & Share $m f$ & $\log ($ sq.f., $s f)$ & $\log ($ sq.f., $m f)$ \\
\hline Built 1980 & $\begin{array}{c}-0.0611 * * * \\
(0.0156)\end{array}$ & $\begin{array}{c}0.0129 \\
(0.0202)\end{array}$ & $\begin{array}{c}-0.128 * * * \\
(0.0425)\end{array}$ \\
\hline Built 1981 & $\begin{array}{c}-0.0849 * * * \\
(0.0177)\end{array}$ & $\begin{array}{c}0.0855 * * * \\
(0.0242)\end{array}$ & $\begin{array}{l}-0.0270 \\
(0.0548)\end{array}$ \\
\hline Built 1982 & $\begin{array}{c}-0.0999 * * * \\
(0.0231)\end{array}$ & $\begin{array}{c}0.0275 \\
(0.0282)\end{array}$ & $\begin{array}{l}-0.0978 \\
(0.0627)\end{array}$ \\
\hline Built 1983 & $\begin{array}{c}-0.144 * * * \\
(0.0244)\end{array}$ & $\begin{array}{l}-0.0123 \\
(0.0292)\end{array}$ & $\begin{array}{l}-0.0630 \\
(0.0715)\end{array}$ \\
\hline Built 1984 & $\begin{array}{c}-0.102 * * * \\
(0.0253)\end{array}$ & $\begin{array}{c}0.0116 \\
(0.0312)\end{array}$ & $\begin{array}{l}-0.0570 \\
(0.0715)\end{array}$ \\
\hline Built 1985 & $\begin{array}{c}-0.108 * * * \\
(0.0278)\end{array}$ & $\begin{array}{l}0.0913 * * \\
(0.0404)\end{array}$ & $\begin{array}{c}0.0288 \\
(0.0979)\end{array}$ \\
\hline Built 1986 & $\begin{array}{c}-0.156 * * * \\
(0.0322)\end{array}$ & $\begin{array}{c}0.144 * * * \\
(0.0450)\end{array}$ & $\begin{array}{c}0.109 \\
(0.107)\end{array}$ \\
\hline Built 1987 & $\begin{array}{c}-0.214 * * * \\
(0.0325)\end{array}$ & $\begin{array}{c}0.164 * * * \\
(0.0463)\end{array}$ & $\begin{array}{l}0.0947 \\
(0.127)\end{array}$ \\
\hline Built 1988 & $\begin{array}{c}-0.226 * * * \\
(0.0345)\end{array}$ & $\begin{array}{c}0.222 * * * \\
(0.0509)\end{array}$ & $\begin{array}{c}0.186 \\
(0.126)\end{array}$ \\
\hline Built 1989 & $\begin{array}{c}-0.271 * * * \\
(0.0368)\end{array}$ & $\begin{array}{c}0.227 * * * \\
(0.0551)\end{array}$ & $\begin{array}{c}0.205 \\
(0.141)\end{array}$ \\
\hline Built 1990 & $\begin{array}{c}-0.282 * * * \\
(0.0412)\end{array}$ & $\begin{array}{c}0.217 * * * \\
(0.0646)\end{array}$ & $\begin{array}{c}0.274 \\
(0.171)\end{array}$ \\
\hline Built 1991 & $\begin{array}{c}-0.327 * * * \\
(0.0412)\end{array}$ & $\begin{array}{l}0.253 * * * \\
(0.0686)\end{array}$ & $\begin{array}{c}0.226 \\
(0.175)\end{array}$ \\
\hline Built 1992 & $\begin{array}{c}-0.380 * * * \\
(0.0426)\end{array}$ & $\begin{array}{c}0.210 * * * \\
(0.0721)\end{array}$ & $\begin{array}{c}0.223 \\
(0.185)\end{array}$ \\
\hline Built 1993 & $\begin{array}{c}-0.416^{* * * *} \\
(0.0452)\end{array}$ & $\begin{array}{l}0.202 * * * \\
(0.0749)\end{array}$ & $\begin{array}{c}0.116 \\
(0.193)\end{array}$ \\
\hline Built 1994 & $\begin{array}{c}-0.394 * * * \\
(0.0436)\end{array}$ & $\begin{array}{c}0.223 * * * \\
(0.0773)\end{array}$ & $\begin{array}{c}0.277 \\
(0.189)\end{array}$ \\
\hline Built 1995 & $\begin{array}{c}-0.376^{* * * *} \\
(0.0430)\end{array}$ & $\begin{array}{c}0.257 * * * \\
(0.0780)\end{array}$ & $\begin{array}{c}0.251 \\
(0.199)\end{array}$ \\
\hline Built 1996 & $\begin{array}{c}-0.418 * * * \\
(0.0478)\end{array}$ & $\begin{array}{c}0.271 * * * \\
(0.0872)\end{array}$ & $\begin{array}{c}0.351 \\
(0.217)\end{array}$ \\
\hline Built 1997 & $\begin{array}{c}-0.397 * * * \\
(0.0509)\end{array}$ & $\begin{array}{l}0.284 * * * \\
(0.0915)\end{array}$ & $\begin{array}{l}0.418 * \\
(0.233)\end{array}$ \\
\hline Built 1998 & $\begin{array}{c}-0.408 * * * \\
(0.0535)\end{array}$ & $\begin{array}{c}0.298 * * * \\
(0.0970)\end{array}$ & $\begin{array}{l}0.429 * \\
(0.254)\end{array}$ \\
\hline Built 1999 & $\begin{array}{c}-0.444 * * * \\
(0.0544)\end{array}$ & $\begin{array}{c}0.355 * * * \\
(0.106)\end{array}$ & $\begin{array}{c}0.578 * * \\
(0.263)\end{array}$ \\
\hline Built 2000 & $\begin{array}{c}-0.450 * * * \\
(0.0566)\end{array}$ & $\begin{array}{c}0.408 * * * \\
(0.110)\end{array}$ & $\begin{array}{c}0.598 * * \\
(0.273)\end{array}$ \\
\hline Built 2001 & $\begin{array}{c}-0.504 * * * \\
(0.0609)\end{array}$ & $\begin{array}{c}0.416 * * * \\
(0.120)\end{array}$ & $\begin{array}{c}0.633 * * \\
(0.295)\end{array}$ \\
\hline Built 2002 & $\begin{array}{c}-0.500 * * * \\
(0.0610)\end{array}$ & $\begin{array}{c}0.433 * * * \\
(0.117)\end{array}$ & $\begin{array}{l}0.555^{*} \\
(0.287)\end{array}$ \\
\hline Built 2003 & $\begin{array}{c}-0.506^{* * * *} \\
(0.0622)\end{array}$ & $\begin{array}{c}0.433 * * * \\
(0.121)\end{array}$ & $\begin{array}{c}0.794 * * * \\
(0.290)\end{array}$ \\
\hline Built 2004 & $\begin{array}{c}-0.487 * * * \\
(0.0699)\end{array}$ & $\begin{array}{c}0.486^{* * * *} \\
(0.121)\end{array}$ & $\begin{array}{c}0.407 \\
(0.297) \\
\end{array}$ \\
\hline
\end{tabular}

Notes: Robust standard errors in parentheses. $* * *$ Significant at $1 \%$; ** significant at $5 \%$; significant at $10 \%$. 
Table A3

Base Specifications but with Contemporaneous / 2-Year Lagged Explanatory Variables Dependent variables: Characteristics of newly built housing stock

\begin{tabular}{|c|c|c|c|}
\hline & $(1)$ & $(2)$ & $(3)$ \\
\hline & $\begin{array}{l}\text { Share } m f \\
\text { units }\end{array}$ & $\begin{array}{l}\log \text { (unit sq. } \\
\text { foot, } s f \text { ) }\end{array}$ & $\begin{array}{l}\text { Log (unit sq. } \\
\text { foot, } m f \text { ) }\end{array}$ \\
\hline \multicolumn{4}{|c|}{ Panel A: Contemporaneous explanatory variables } \\
\hline $\begin{array}{l}\text { Log(Personal income per capita }) \\
\text { contemporaneous }\end{array}$ & $\begin{array}{c}0.659 * * * \\
(0.147)\end{array}$ & $\begin{array}{c}-0.541 * * \\
(0.263)\end{array}$ & $\begin{array}{c}-1.724 * * * \\
(0.612)\end{array}$ \\
\hline $\begin{array}{l}\text { Log(Construction sector annual wage per employee), } \\
\text { contemporaneous }\end{array}$ & $\begin{array}{c}-0.137 \\
(0.0988)\end{array}$ & $\begin{array}{l}0.0557 \\
(0.115)\end{array}$ & $\begin{array}{l}-0.0731 \\
(0.325)\end{array}$ \\
\hline Metro area $\times$ AHS-year fixed effects & Yes & Yes & Yes \\
\hline Year built-fixed effects & Yes & Yes & Yes \\
\hline Constant & $\begin{array}{c}-4.678 * * * \\
(1.101)\end{array}$ & $\begin{array}{c}12.47 * * * \\
(2.182)\end{array}$ & $\begin{array}{c}25.58 * * * \\
(4.769)\end{array}$ \\
\hline Observations & 1829 & 1548 & 1513 \\
\hline Number of AHS-year x metro area combinations & 167 & 167 & 167 \\
\hline \multirow{3}{*}{$\begin{array}{ll}\text { R-squared } & \text { within } \\
& \text { between } \\
& \text { overall }\end{array}$} & 0.243 & 0.178 & 0.071 \\
\hline & 0.295 & 0.043 & 0.000 \\
\hline & 0.227 & 0.040 & 0.003 \\
\hline \multicolumn{4}{|c|}{$\begin{array}{ll}\text { Panel B: 2-year lagged explanatory variables } \\
\end{array}$} \\
\hline $\begin{array}{l}\text { Log(Personal income per capita), } \\
\text { 2-year lagged }\end{array}$ & $\begin{array}{c}0.536^{* * *} \\
(0.141)\end{array}$ & $\begin{array}{c}-0.407 * * \\
(0.192)\end{array}$ & $\begin{array}{c}-1.251 * * \\
(0.511)\end{array}$ \\
\hline $\begin{array}{l}\text { Log(Construction sector annual wage per employee), } \\
\text { 2-year lagged }\end{array}$ & $\begin{array}{l}-0.103 \\
(0.124)\end{array}$ & $\begin{array}{l}-0.0227 \\
(0.105)\end{array}$ & $\begin{array}{c}0.394 \\
(0.295)\end{array}$ \\
\hline Metro area $\times$ AHS-year fixed effects & Yes & Yes & Yes \\
\hline Year built-fixed effects & Yes & Yes & Yes \\
\hline Constant & $\begin{array}{c}-3.788 * * * \\
(1.044) \\
\end{array}$ & $\begin{array}{c}11.94 * * * \\
(1.683) \\
\end{array}$ & $\begin{array}{c}15.82 * * * \\
(4.751) \\
\end{array}$ \\
\hline Observations & 1829 & 1548 & 1513 \\
\hline Number of AHS-year x metro area combinations & 167 & 167 & 167 \\
\hline \multirow{3}{*}{$\begin{array}{ll}\text { R-squared } & \text { within } \\
& \text { between } \\
& \text { overall } \\
\end{array}$} & 0.235 & 0.174 & 0.053 \\
\hline & 0.346 & 0.061 & 0.002 \\
\hline & 0.253 & 0.052 & 0.003 \\
\hline
\end{tabular}

Notes: Robust standard errors in parentheses. $* * *$ Significant at $1 \% ; * *$ significant at 5\%; $*$ significant at $10 \%$. 
Table A4

Base Specifications but with Shorter Window

Dependent variables: Characteristics of newly built housing stock

\begin{tabular}{|c|c|c|c|c|}
\hline & (1) & $(2)$ & (3) & $(4)$ \\
\hline & \multicolumn{2}{|c|}{$\begin{array}{c}\text { Share } m f \\
\text { units } \\
\end{array}$} & $\begin{array}{l}\text { Log (unit sq. } \\
\quad \text { foot, } s f \text { ) }\end{array}$ & $\begin{array}{l}\text { Log (unit sq. } \\
\text { foot, } m f \text { ) }\end{array}$ \\
\hline & $\begin{array}{l}10 \text { year } \\
\text { window }\end{array}$ & $\begin{array}{c}5 \text { year } \\
\text { window }\end{array}$ & $\begin{array}{c}5 \text { year } \\
\text { window }\end{array}$ & $\begin{array}{c}5 \text { year } \\
\text { window }\end{array}$ \\
\hline $\begin{array}{l}\text { Log(Personal income per capita), } \\
\text { 1-year lagged }\end{array}$ & $\begin{array}{l}0.643 * * * \\
(0.146)\end{array}$ & $\begin{array}{l}0.433 * \\
(0.234)\end{array}$ & $\begin{array}{c}-0.450 * * \\
(0.220)\end{array}$ & $\begin{array}{c}-1.853 * * * \\
(0.686)\end{array}$ \\
\hline $\begin{array}{l}\text { Log(Construction sector annual wage } \\
\text { per employee }), 1 \text {-year lagged }\end{array}$ & $\begin{array}{l}-0.0759 \\
(0.109)\end{array}$ & $\begin{array}{l}0.0561 \\
(0.157)\end{array}$ & $\begin{array}{l}-0.0110 \\
(0.129)\end{array}$ & $\begin{array}{l}-0.215 \\
(0.423)\end{array}$ \\
\hline Metro area $\times$ AHS-year FEs & Yes & Yes & Yes & Yes \\
\hline Year built-fixed effects & Yes & Yes & Yes & Yes \\
\hline Constant & $\begin{array}{c}-5.182 * * * \\
(1.229)\end{array}$ & $\begin{array}{l}-4.535^{* *} \\
(2.156)\end{array}$ & $\begin{array}{l}12.29 * * * \\
(1.941)\end{array}$ & $\begin{array}{l}28.29 * * * \\
(6.792)\end{array}$ \\
\hline Observations & 1548 & 973 & 973 & 949 \\
\hline $\begin{array}{l}\text { Number of AHS-year x metro area } \\
\text { combinations }\end{array}$ & 167 & 167 & 167 & 167 \\
\hline R-squared $\quad$ within & 0.204 & 0.159 & 0.165 & 0.067 \\
\hline between & 0.160 & 0.101 & 0.038 & 0.000 \\
\hline overall & 0.272 & 0.209 & 0.052 & 0.004 \\
\hline
\end{tabular}

Notes: Robust standard errors in parentheses. $* * *$ Significant at $1 \%$;* significant at $5 \%$; $*$ significant at $10 \%$. 


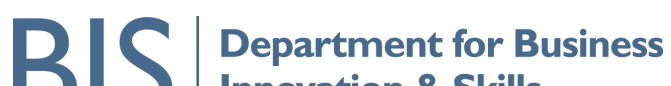 BIS}

\section{Spatial Economics Research Centre (SERC)}

London School of Economics

Houghton Street

London WC2A 2AE

Tel: 02078523565

Fax: 02079556848

Web: www.spatialeconomics.ac.uk

SERC is an independent research centre funded by the Economic and Social Research Council (ESRC), Department for Business Innovation and Skills (BIS) and the Welsh Government. 